\title{
Microfossil assemblages and geochemistry for interpreting the incidence of the Jenkyns Event (early Toarcian) in the south-eastern Iberian Palaeomargin (External Subbetic, SE Spain)
}

\author{
Matías Reolid \\ Departamento de Geología, Universidad de Jaén, 23071 Jaén, Spain \\ Correspondence: Matías Reolid (mreolid@ujaen.es)
}

Received: 31 July 2020 - Revised: 23 October 2020 - Accepted: 26 October 2020 - Published: 4 December 2020

\begin{abstract}
By studying the facies, geochemistry, and microfossil assemblages of the uppermost Pliensbachian and lower Toarcian of the Cueva del Agua section, I was able to appraise the impact of the Jenkyns Event in the eastern part of the South Iberian Palaeomargin (Western Tethys). Depleted oxygen conditions are envisaged for the Polymorphum-Serpentinum Zone boundary (lower Toarcian), represented by dark marls, precisely in a laminated interval. The decrease in the $\alpha$ diversity of foraminifera and ostracods, along with greater proportions of opportunists such as Lenticulina, Eoguttulina, and Cytherella just before the negative carbon isotopic excursion (CIE), would indicate a disturbance of the environmental conditions during the initial phase of the biotic crisis. The peak of the biotic crisis is characterized by an absence of trace fossils, increased organic matter content, an increased $\mathrm{Mo} / \mathrm{Al}$ ratio, and negative $\mathrm{CIE}$ and $\delta^{18} \mathrm{O}$, as well as fewer specialist forms and more opportunists. This biotic crisis peak is related to oxygen-depleted conditions in the bottom waters and in the sediment pore water, while warming negatively affected microfauna - to the point of leaving a barren benthic horizon in the record. Recovery is evidenced by the occurrence of carbonate layers with hummocky cross-stratification and a decrease in organic matter content, the Mo/Al ratio, and the trace fossil record. In terms of microfauna, the first phase of recovery shows highly abundant foraminifera, ostracods, and microgastropods, mainly opportunist forms. After the proliferation of opportunist forms, a second phase of recovery is marked by a progressive increase in $\alpha$ diversity.
\end{abstract}

\section{Introduction}

Research on environmental global events that affected past marine ecosystems offers us the chance to elaborate models for understanding ongoing worldwide changes. The Toarcian oceanic anoxic event (T-OAE; Early Jurassic), also known as the Jenkyns Event (Müller et al., 2017; Reolid et al., 2020a), is a very useful past analogue. This global event was an abrupt palaeoenvironmental perturbation entailing marine transgression (Hallam, 1987; Pittet et al., 2014; Haq, 2018) coeval with a widespread deposition of black shales (Jenkyns, 1988; Bellanca et al., 1999; Röhl et al., 2001; McArthur, 2019), global warming (e.g. García Joral et al., 2011; Korte and Hesselbo, 2011; Suan et al., 2011; Danise et al., 2013; Them et al., 2017; Baghli et al., 2020; Piazza et al., 2020; Storm et al., 2020), and enhanced weathering (e.g. Montero-Serrano et al., 2015; Fu et al., 2017; Reolid et al., 2020b). A perturbation of the carbon cycle indicated by a negative carbon isotopic excursion (CIE) affected marine environments (e.g. Jenkyns and Clayton, 1986; Sælen et al., 1996; Suan et al., 2010; Reolid, 2014a; Baghli et al., 2020) and land ecosystems (as evidenced in land plant organic matter; e.g. Hesselbo et al., 2007; Ruebsam et al., 2020a). This global change led to a biotic crisis constituting a secondorder mass extinction for benthic organisms (Little and Benton, 1995; Aberhan and Fürsich, 2000; Cecca and Macchioni, 2004; Wignall et al., 2005; Gomez and Goy, 2011; Danise et al., 2013, 2019; Caruthers et al., 2014; Rita et al., 2016), 
probably driven by oxygen depletion affecting many platforms and deep oceanic environments (Röhl et al., 2001; Bucefalo Palliani et al., 2002; Wignall et al., 2005; Hermoso et al., 2009; Caruthers et al., 2014; Them et al., 2018; Reolid et al., 2012a, 2019a). Oxygen-depleted conditions in marine ecosystems in some areas reached generalized anoxia and euxinia (e.g. Gill et al., 2011; Izumi et al., 2018; Ruebsam et al., 2018; Suan et al., 2018) but did not affect all basins and palaeomargins alike (e.g. Boomer et al., 2009; Reolid et al., 2014a, 2015; McArthur, 2019). Reolid et al. (2020a) propose the use of the term T-OAE only when studying marine deposits holding evidence of oxygen-depleted conditions; the term Jenkyns Event (Müller et al., 2017) is more appropriate for the global changes that occurred during the early Toarcian (including the anoxic event).

In the context of oceanic anoxic events, the response of microfossil organisms before, during, and after a biotic crisis can prove useful for interpreting controlling environmental factors such as oxygen availability and nutrient input (Bartolini et al., 1992; Hylton and Hart, 2000; Gebhardt et al., 2004; Friedrich et al., 2009; Mailliot et al., 2009; Nikitenko et al., 2013; Rita et al., 2016; Jozsa et al., 2018; Reolid et al., 2019a, b). Assemblages of benthic foraminifera and ostracods (composition, $\alpha$ diversity, and abundance) are good bioindicators of physicochemical parameters at the seafloor, including oxygen and trophic resource availability (Benson et al., 1983; Whatley, 1988; Dingle and Lord, 1990; Sjoerdsma and Van der Zwaan, 1992; Cronin et al., 1994, 1995, 2002; Jorissen et al., 1995; Whatley, 1995; Van der Zwaan et al., 1999; Fontanier et al., 2002; N'Zaba-Makaya et al., 2003; Olóriz et al., 2003; Ayress et al., 2004; Reolid et al., 2008a). The depth in the sediment at which foraminifera live is predominantly determined by food quality and secondarily by oxygen availability (Nagy, 1992; Tyszka, 1994; Jorissen et al., 1995; Van der Zwaan et al., 1999; Fontanier et al., 2002; Ernst and Van der Zwaan, 2004; Reolid et al., 2008b; Olóriz et al., 2012). Corbari (2004) indicates that the movement of Ostracoda from an infaunal to an epifaunal microhabitat occurs when the redox boundary becomes shallower in the sediment and the predation of ostracods increases. Epifaunal forms have an advantage in environments that are subjected to food and/or oxygen limitations except when they are submitted to high predation pressure, whereas infaunal taxa tend to proliferate when food and oxygen are more plentiful within the sediment (Jorissen et al., 1995; Van der Zwaan et al., 1999). Records of microfossil assemblages with high opportunist-to-specialist ratios and reduced diversity are indicative of ecological stress and unfavourable conditions at the seafloor (Sjoerdsma and Van der Zwaan, 1992; Hylton and Hart, 2000; Rita et al., 2016; Alegret et al., 2018; Reolid et al., 2019a, b).

The objective of this work is to derive an environmental interpretation of the incidence of the Jenkyns Event and shed light on the development of the T-OAE in the South Iberian Palaeomargin based on the analysis of microfossil assem- blages together with microfacies and geochemical proxies, with a description of the microfossil population dynamics before, during, and after the event. The Subbetic is an ideal arena for such a study, as the South Iberian Palaeomargin was not affected by generalized bottom anoxia, and the typical black shales are not recorded (e.g. Rodríguez-Tovar and Reolid, 2013; Reolid et al., 2015, 2020b). Given these circumstances, the effect of global warming on the foraminifera and ostracods, or other factors, may be tested.

\section{Geological setting}

The studied section, Cueva del Agua, is found in southern Spain in a ravine of the same name $\left(37^{\circ} 54^{\prime} 20.1^{\prime \prime} \mathrm{N}\right.$, $02^{\circ} 32^{\prime} 61.0^{\prime \prime} \mathrm{W}$ ) just $11 \mathrm{~km}$ north-west of the village of Huéscar (Granada Province). From a geological standpoint the section pertains to the External Subbetic, more specifically to the Betic External Zones (northern part of the Betic Cordillera, Fig. 1a; Vera, 2001). The sedimentary rocks of the external zones represent the evolution of the South Iberian Palaeomargin from Triassic to Paleogene times (Reolid et al., 2018). They mainly correspond to carbonate and marly sediments deposited in the palaeomargin located in the Western Tethys. The upper Pliensbachian and Toarcian are recorded in the Zegrí Formation (Fig. 1b). Three facies can be discerned in the Cueva del Agua section (Fig. 1c): (a) marl and marly limestone alternation, (b) dark marls, and (c) thinbedded limestones.

The upper Pliensbachian is constituted by an alternation of grey marls and marly limestone (Fig. 2a). The ammonite assemblage is composed by Canavaria elisa, Emaciaticeras emaciatum, E. imitator, E. lotti, Lioceratoides aradasi, and Protogrammoceras bassanii (Emaciatum Zone, upper Pliensbachian) followed by the first record of Dactylioceras (Eodactylioceras) polymorphum of the Polymorphum Zone (lower Toarcian). Ammonoids are more common at the top of the Pliensbachian. The limestone beds are around 20$30 \mathrm{~cm}$ thick and are densely bioturbated by Planolites, Thalassinoides, and Chondrites. The microfacies are mudstones and locally wackestones.

Found above this lithofacies is $16 \mathrm{~m}$ of dark marls (Fig. 2b-d) corresponding to the Polymorphum Zone and the lower part of the Serpentinum Zone (Levisoni Zone for Mediterranean biozonation and Falciferum Zone for subboreal biozonation). In the lower part of the dark marls only scarce Chondrites are recorded. The most clayey interval, $50 \mathrm{~cm}$ thick, is located in the Polymorphum-Serpentinum Zone boundary (Fig. 2c) some $8 \mathrm{~m}$ atop the alternating marls and marly limestones. Although it shows the characteristic dark colour and thinly laminated fabric, it lacks trace fossils (Fig. 2d).

In the upper part of the dark marls the limestone beds are progressively more common, consisting of thin calcarenites and calcisiltites. Trace fossils become more abundant in 

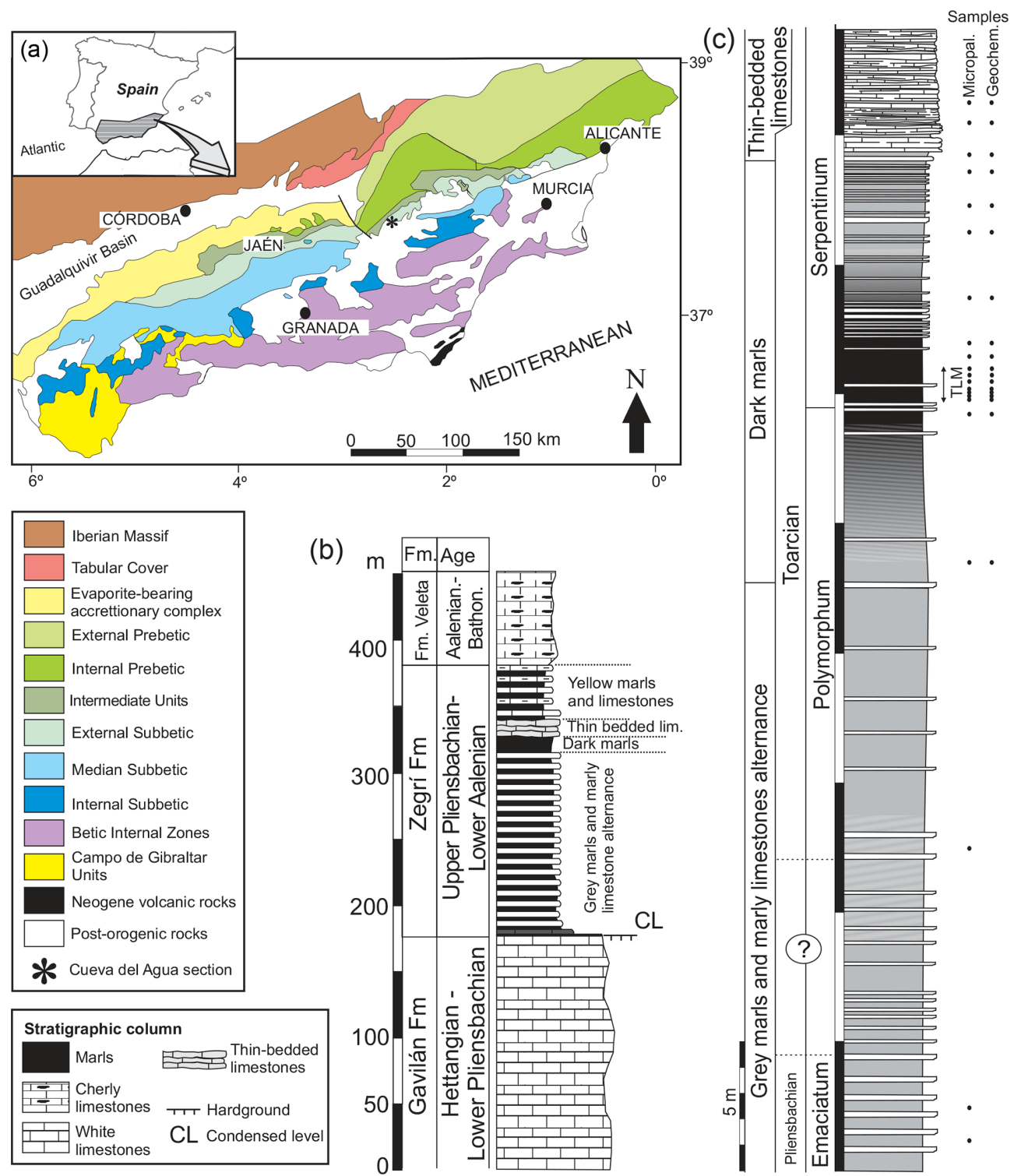

Figure 1. Geological setting of the Cueva del Agua section. (a) General geological map of the Betic Cordillera with the location of the Cueva del Agua section. (b) General Lower and Middle Jurassic succession of the Subbetic including the Zegrí Formation. (c) Detailed log of the Cueva del Agua section with the position of samples for micropalaeontology and geochemistry. Note that TLM stands for thin-laminated dark marls.

this stratigraphic interval, mainly Chondrites and secondarily Planolites $(<6 \mathrm{~mm}$ in diameter).

The dark marls are overlain by $13 \mathrm{~m}$ of thin-bedded limestones assigned to the lower part of the Serpentinum Zone (Jiménez, 1986; Fig. 2b, e-h). This lithofacies is made up of irregular layers $(7-15 \mathrm{~cm}$ thick) with parallel and wavy laminations, typical of hummocky cross-stratification (HCS; Fig. 2e). The base of these beds is bioturbated (Fig. 2f). Microfacies are constituted by laminated bands of radiolarids and less common micritic bands, separated by thin surfaces rich in iron oxides (Fig. $2 \mathrm{~g}$ and $\mathrm{h}$ ). In the studied section, ammonoids are absent within this lithofacies, yet the age as- signed is Serpentinum Zone, as proposed by Jiménez (1986) for other sections where ammonoids are recorded.

This work was focused on the geochemistry and the microfossil assemblages, mainly foraminifera and ostracods, recorded in the dark marl interval across the PolymorphumSerpentinum Zone boundary. This interval is considered to reflect the global change (Jenkyns Event; see Reolid et al., 2020a) that produced oxygen-depleted conditions at the bottom related to the Toarcian oceanic anoxic event (T-OAE). 

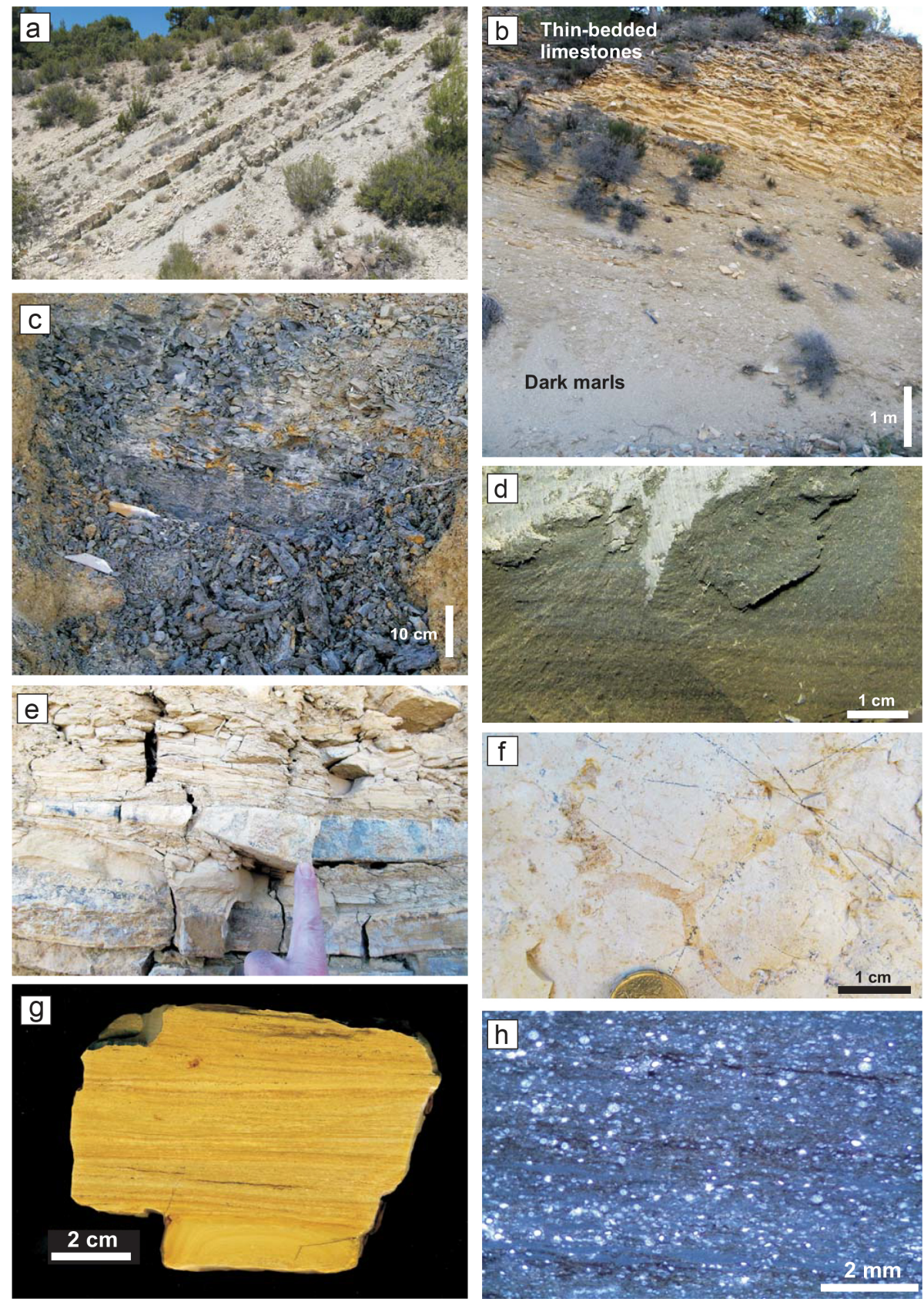

Figure 2. Facies and microfacies of the Cueva del Agua section. (a) Field view of the alternating marls and marly limestone in the Emaciatum Zone (upper Pliensbachian). (b) Contact between Toarcian dark marls and thin-bedded limestones. (c) Detailed view of the dark marls of the Polymorphum-Serpentinum Zone boundary. (d) Close view of the thin-laminated dark marls of the base of Serpentinum Zone. (e) Thinbedded limestones of the Serpentinum Zone. (f) Trace fossil from the wall of a calcisiltite bed of the thin-bedded limestone. (g) Polished slab from the thin-bedded limestone showing lamination. (h) Microfacies of the thin-bedded limestones with laminae constituted by radiolarians.

\section{Material and methods}

A $19.2 \mathrm{~m}$ thick interval that included the upper part of the Polymorphum Zone and the lower part of the Serpentinum Zone was analysed through a total of 18 marl samples collected mainly around the Polymorphum-Serpentinum Zone boundary proposed by Reolid et al. (2018).
For $\delta^{13} \mathrm{C}$ analysis of bulk carbonate, after roasting, the samples were reacted at $73^{\circ} \mathrm{C}$ in an automated carbonate reaction system (Kiel-IV) coupled directly to the inlet of a Finnigan MAT 253 gas ratio mass spectrometer at the Laboratory of Stable Isotopes of the University of Michigan. Isotopic ratios are reported in per mill notation relative to the $\mathrm{Vi-}$ enna PeeDee Belemnite (VPDB) standard. Values were cali- 
brated using NBS 19 as the primary standard, and the analytical precision was monitored by daily analysis of NBS powdered carbonate standards (1.95\% VPDB). Precision was over $0.02 \%$ for $\delta^{13} \mathrm{C}$.

$\mathrm{The} \mathrm{Mo} / \mathrm{Al}$ ratio was analysed as a proxy for redox conditions (e.g. Gallego-Torres et al., 2007; Reolid et al., 2012a; Rodríguez-Tovar and Reolid, 2013). Al was detected by Xray fluorescence (XRF) in a Philips PW 1040/10 spectrometer at the Centro de Instrumentación Científica (CIC; Universidad de Granada). The Mo was determined using an inductively coupled plasma mass spectrometer (ICP-MS Perkin Elmer Sciex-Elan 5000), also at the CIC. The instrumental error was $\pm 5 \%$. Mo content was normalized to $\mathrm{Al}$ content (Calvert and Pedersen, 1993), assuming that Al is mainly hosted by alumino-silicates (e.g. Calvert, 1990). The total organic carbon (TOC) content was analysed by acid leaching in the laboratories of SGS Canada Inc. (Ontario). The results were provided in milligrams and calculated as percentages of sample weight. The precision and accuracy of this method are approximately $0.01 \%$ and $92 \%$, respectively.

A total of 21 samples underwent analysis for microfossil assemblages, some from the top of the Emaciatum Zone (uppermost Pliensbachian), but special attention was paid to the upper part of the Polymorphum Zone and the lower Serpentinum Zone (where 16 marl samples were selected). While samples from the top of the Emaciatum Zone and the lower part of the Polymorphum Zone served for comparison with assemblages affected by the early Toarcian biotic crisis, additional analyses of the Pliensbachian-Toarcian boundary were necessary. For microfossil assemblage analysis, about $300 \mathrm{~g}$ of dried rock was reduced into small pieces. The material was introduced into water or into an acetic acid $\left(\mathrm{C}_{2} \mathrm{H}_{4} \mathrm{O}_{2}\right)$ solution, depending on the carbonate content of the rock (for the highest carbonate contents, $70 \%$ acid was used with $30 \%$ distilled water). Shell dissolution was controlled when acetic acid was employed. When the rock disaggregated, each sample was rinsed in a column of standard stainless-steel sieves having openings of $1 \mathrm{~mm}, 500 \mu \mathrm{m}$, $200 \mu \mathrm{m}, 100 \mu \mathrm{m}$, and $53 \mu \mathrm{m}$ with a jet of water at the top. After this procedure, residues were oven-dried at $35^{\circ} \mathrm{C}$ and finally weighed. Foraminifera, ostracods, microgastropods, and echinoderm remains were hand-picked from 200 and $100 \mu \mathrm{m}$ fractions with a hair paintbrush on a standard black picking grid tray under a SZ-PT Olympus microscope in the Department of Geology (Univ. Jaén). The fractions $>500 \mu \mathrm{m}$ were generally poor in foraminifera and ostracods in the studied section, but echinoderm and mollusc fragments could be recorded. Each studied portion was properly weighed. All these sample residues and specimens are stored at the Department of Geology of the Universidad de Jaén (Collection Toarcian IGCP-655, Cueva del Agua).

The images of foraminifera were obtained from the Centro de Instrumentación Científico-Técnica of the University of Jaén (Spain), with secondary electrons in a Merlin Carl Zeiss scanning electron microscope (SEM). The absolute abundances of both foraminifera and ostracods (specimens per $100 \mathrm{~g}$ of rock) were calculated throughout the studied interval, along with their relative abundances $(\%)$. The $\alpha$ diversity index of Fisher et al. (1943) was calculated for the foraminiferal assemblages.

Studies based on modern and ancient foraminiferal shells demonstrate that the mode of coiling, chamber arrangement, position of perforations, and features of aperture, among other aspects, are directly related to different lifestyles and trophic strategies (Corliss, 1985, 1991; Jones and Charnock, 1985; Nagy, 1992; Tyszka, 1994). This work follows the morphogroup nomenclature proposed for Jurassic foraminifera by Reolid et al. (2008b, 2012b) and modified by Rita et al. (2016) and Reolid et al. (2019b). A total of nine morphogroups were individualized (C, D, E, F, G, H, I, J, and $\mathrm{K}$ ) in view of morphological features (test form, chamber arrangement, and mode of coiling), corresponding primarily to distinct lifestyles and secondly trophic strategies (Fig. 3). Morphogroup J can be divided into subgroups J1J4. In this work, foraminifera living up to $1 \mathrm{~cm}$ deep in the sediment are considered to be epifaunal (e.g. Corliss, 1991), whereas shallow infaunal forms inhabit depths between 1 and $5 \mathrm{~cm}$ (e.g. Kuhnt et al., 1996). The potentially deep infauna includes forms that can inhabit depths of more than $5 \mathrm{~cm}$ below the seafloor (e.g. Kuhnt et al., 1996; Reolid et al., 2019a, b; Wasim et al., 2020).

\section{Results}

\subsection{Geochemistry}

The main changes in geochemistry occur at the base of the Serpentinum Zone. The $\mathrm{CaCO}_{3}$ content abruptly decreases in the dark marl interval of the Serpentinum Zone, where values are usually $<42 \%$ (Fig. 4). The carbonate content is recovered in the thin-bedded limestones at the top of the section. The TOC values are very low, commonly $<0.2 \mathrm{wt} \%$, but at the base of the Serpentinum Zone they abruptly increase to $0.53 \%$ within the clay-rich interval of the thinlaminated dark marls (Fig. 4). Above this interval the TOC newly decreases to values $<0.1 \mathrm{wt} \%$. A similar trend is seen for total sulfur (TS) content, with very low values in the section $(<0.02 \%)$ except for the base of the Serpentinum Zone, where it reaches $0.32 \%$ (Fig. 4). Pyrite framboids are abundant in the $100-53 \mu \mathrm{m}$ fraction of the sieved samples from the dark marls yet also recovered from larger fractions (Fig. 5a, b). The concentrations of redox-sensitive elements, such as Mo, show trends similar to those of TOC and TS, the highest values being recorded in the thin-laminated dark marls (Fig. 4). In this interval, phosphatic fish remains of indeterminate taxa are quite common, as are Mn oxides and coal fragments (Fig. 5c-e).

The $\delta^{13} \mathrm{C}$ values range from $-1.87 \%$ to $1.83 \%$, with the beginning of a negative CIE in the thin-laminated dark marls of the Serpentinum Zone coinciding with the highest TOC 


\begin{tabular}{|c|c|c|c|c|c|c|}
\hline \multicolumn{3}{|c|}{ Morphogroup } & Test form & Life-style & Feeding strategy & Genera \\
\hline \multirow{5}{*}{ 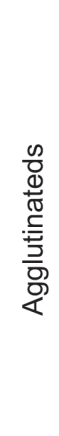 } & \multirow{3}{*}{ C } & C1 & Elongated uniserial & $\begin{array}{l}\text { Shallow to } \\
\text { deep infaunal }\end{array}$ & $\begin{array}{c}\text { Detritivores } \\
\text { bacterial scavengers }\end{array}$ & Reophax \\
\hline & & $\mathrm{C} 2$ & $\begin{array}{l}\text { Elongated uniserial, } \\
\text { initial planispiral or } \\
\text { streptospiral coiling }\end{array}$ & Shallow infaunal & $\begin{array}{c}\text { Detritivores } \\
\text { bacterial scavengers }\end{array}$ & Ammobaculites \\
\hline & & C3 & $\begin{array}{l}\text { Elongated biserial, } \\
\text { triserial and } \\
\text { high trochospiral }\end{array}$ & $\begin{array}{l}\text { Shallow to } \\
\text { deep infaunal }\end{array}$ & $\begin{array}{c}\text { Detritivores } \\
\text { bacterial scavengers }\end{array}$ & Textularia \\
\hline & \multicolumn{2}{|c|}{$\mathrm{D}$} & Spiral multilocular & $\begin{array}{c}\text { Epifaunal (to } \\
\text { shallow infaunal) }\end{array}$ & $\begin{array}{c}\text { Active herbivores, } \\
\text { detritivores and } \\
\text { bacterivores }\end{array}$ & Trochammina \\
\hline & \multicolumn{2}{|c|}{$E$} & $\begin{array}{c}\text { Flattened, discoidal, } \\
\begin{array}{c}\text { spiral or irregular coiled } \\
\text { (bilocular) }\end{array}\end{array}$ & Epifaunal, phytal & $\begin{array}{l}\text { Active herbivores, } \\
\text { detritivores }\end{array}$ & $\begin{array}{l}\text { Ammodiscus } \\
\text { Glomospira }\end{array}$ \\
\hline \multirow{8}{*}{ 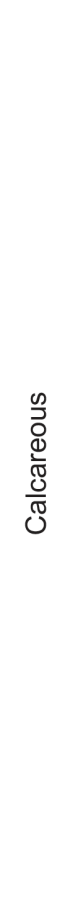 } & \multicolumn{2}{|c|}{$G$} & $\begin{array}{l}\text { Plano-convex } \\
\text { trochospiral }\end{array}$ & Epifaunal & $\begin{array}{l}\text { Primary weed fauna } \\
\text { grazing herbivores }\end{array}$ & Reinholdella \\
\hline & \multicolumn{2}{|c|}{$\mathrm{H}$} & $\begin{array}{l}\text { Discoidal flattened } \\
\text { (planispiral) and } \\
\text { plano-convex } \\
\text { (trochospiral) }\end{array}$ & Epifaunal & $\begin{array}{l}\text { Primary weed fauna } \\
\text { grazing herbivores/ } \\
\text { phytodetritivores }\end{array}$ & $\begin{array}{l}\text { Involutina } \\
\text { Spirillina }\end{array}$ \\
\hline & \multicolumn{2}{|c|}{ I } & $\begin{array}{l}\text { Discoidal flattened } \\
\text { spiral, elongated }\end{array}$ & Epifaunal & $\begin{array}{l}\text { Active deposit-feeders } \\
\text { herbivores, detritivores }\end{array}$ & Ophthalmidium \\
\hline & \multirow{4}{*}{$J$} & $\mathrm{~J} 1$ & Elongated uniserial & Shallow infaunal & $\begin{array}{c}\text { Active deposit-feeders, } \\
\text { herbivores, } \\
\text { bacterial scavengers }\end{array}$ & $\begin{array}{l}\text { Dentalina } \\
\text { Ichthyolaria } \\
\text { Marginulina } \\
\text { Nodosaria } \\
\text { Paralingulina } \\
\text { Pseudonodosaria } \\
\text { Tristix }\end{array}$ \\
\hline & & $\mathrm{J} 2$ & $\begin{array}{l}\text { Elongated flattened, } \\
\text { planispiral evolute } \\
\text { to uniserial }\end{array}$ & Shallow infaunal & $\begin{array}{l}\text { Active deposit-feeders } \\
\text { grazing omnivores }\end{array}$ & $\begin{array}{l}\text { Astacolus } \\
\text { Citharina } \\
\text { Planularia } \\
\text { Vaginulina } \\
\text { Marginulinopsis }\end{array}$ \\
\hline & & J3 & $\begin{array}{l}\text { Elongated with } \\
\text { straight periphery }\end{array}$ & $\begin{array}{l}\text { Shallow to deep } \\
\text { infaunal }\end{array}$ & $\begin{array}{l}\text { Active deposit-feeders } \\
\text { grazing omnivores }\end{array}$ & Eoguttulina \\
\hline & & $\mathrm{J} 4$ & Elongated biserial & Shallow infaunal & $\begin{array}{c}\text { Active deposit-feeders, } \\
\text { herbivores, } \\
\text { bacterial scavengers }\end{array}$ & Bolivina \\
\hline & \multicolumn{2}{|c|}{$\mathrm{K}$} & $\begin{array}{l}\text { Biconvex (lenticular) } \\
\text { planispiral }\end{array}$ & $\begin{array}{c}\text { Epifaunal to deep } \\
\text { infaunal }\end{array}$ & $\begin{array}{l}\text { Active deposit-feeders, } \\
\text { grazing omnivores }\end{array}$ & Lenticulina \\
\hline
\end{tabular}

Figure 3. Calcareous foraminiferal morphogroups for the upper Pliensbachian-lower Toarcian sediments of Cueva del Agua (based on Reolid et al., 2008, 2012a; Rita et al., 2016).

and TS values (Fig. 4). However, the values of $\delta^{13} \mathrm{C}$ do not recover as rapidly as TOC and TS, and $\delta^{13} \mathrm{C}$ decreases to its lowest values $(-1.87 \%$ and $-1.70 \%$ o $)$ just below the thin-bedded limestones (Serpentinum Zone; Jiménez, 1986). Within the thin-bedded limestones $\delta^{13} \mathrm{C}$ increases to as much as $1.83 \%$. The negative CIE is also located in the lower part of the Serpentinum Zone elsewhere in the Subbetic (Reolid, 2014a; Reolid et al., 2014a, 2020b; Rodrigues et al., 2019; Ruebsam et al., 2020a) and in other basins around the world (e.g. Jenkyns and Clayton, 1986; Sælen et al., 1996; Erba, 2004; Mattioli et al., 2004; Tremolada et al., 2005; Wignall et al., 2005; Hesselbo et al., 2007; Suan et al., 2010; Izumi et al., 2012; Xu et al., 2018; Baghli et al., 2020; Ruebsam et al., 2020b).
The $\delta^{18} \mathrm{O}$ values are around $-3 \%$ in the Polymorphum Zone, then show an abrupt decrease to values between $-5.36 \%$ and $-4.95 \%$ in the thin-laminated dark marls at the base of the Serpentinum Zone (Fig. 4). This isotopic excursion has been recorded in other Iberian palaeomargins (Rosales et al., 2004; Gómez and Goy, 2011; Reolid et al., 2014a; Piazza et al., 2020). Above it, $\delta^{18} \mathrm{O}$ increases; values similar to those of the Polymorphum Zone are recovered in the thin-bedded limestones.

\subsection{Foraminiferal assemblages}

Foraminiferal assemblages are dominated by representatives of the suborder Lagenina (mainly genera Lenticulina, Dentalina, Paralingulina, Nodosaria, and Eoguttulina; Fig. 6). 


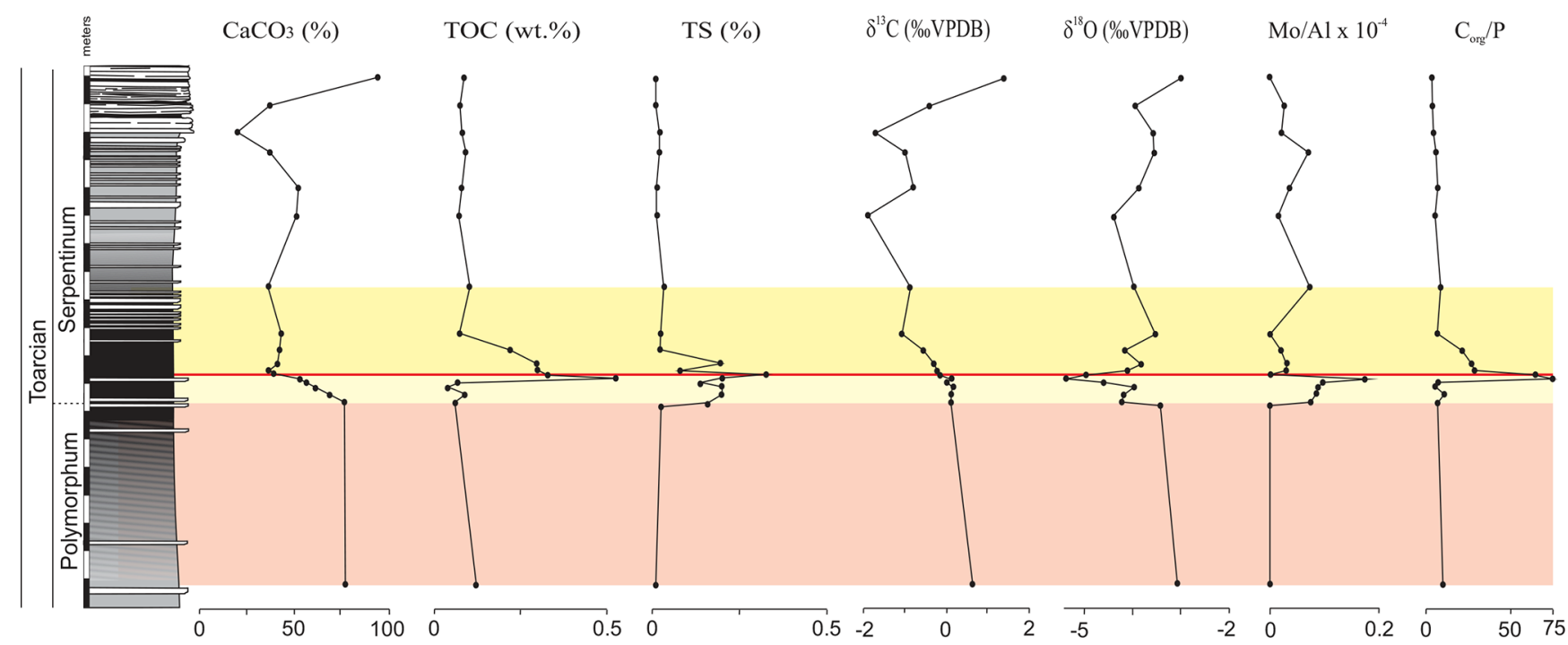

Figure 4. Stratigraphic distribution of the geochemical proxies $\mathrm{CaCO}_{3}$, TOC, TS, $\delta^{13} \mathrm{C}, \delta^{18} \mathrm{O}$, and the Mo/Al ratio in the PolymorphumSerpentinum Zone boundary. The colour bands correspond to the stratigraphic intervals differentiated according to microfossil assemblages (see text), and red lines indicate the position of a barren benthic horizon.

Less common suborders found are Textulariina (mainly corresponding to genera Reophax and Ammobaculites), Spirillinina (Spirillina), Robertinina, and Miliolina (Fig. 6). The molecular classification of foraminifera proposed by Pawloski et al. (2013) is not applied in this work because the position of the most common group in the Tethys, order Lagenida, is uncertain in their classification. Instead, the foraminifera classification used here is based on Loeblich and Tappan (1988) as well as the monographic work of Copestake and Johnson (2014).

Foraminifera are commonly well-preserved in the Cueva del Agua section, fragmentation being largely related to the washing procedure. Abrasion and fragmentation of tests are the main biostratinomic features. In some specimens the fine elements of sculpture and ornamentation are lost or only coarsely represented. Original fragmentation is restricted to the last chambers in the case of uniserial calcitic forms such as Dentalina, Marginulina, Nodosaria, Pseudonodosaria, and Tristix, as well as lenticular forms such as Lenticulina and Astacolus. Fragmentation is common in the genera Glomospira and Lenticulina from the top of the Emaciatum Zone. Fossil diagenetic features include some specimens with recrystallized tests lacking evidence of dissolution.

The top of the Pliensbachian is dominated by the uniserial forms of MG-J1 (from $77 \%$ to $36 \%$ ), mainly Dentalina (Fig. 7). Secondary forms correspond to MG-J3 (genus Eoguttulina) and MG-K (genus Lenticulina). According to lifestyle, the shallow infaunal forms, being specialists, prevail. The lower part of the Polymorphum Zone, corresponding to the grey marls and marly limestone alternation, features a dominance of uniserial forms of the MG-J1 (rang- ing from $44 \%$ to $25 \%$ ), especially Dentalina and Nodosaria (Fig. 7). Secondary morphogroups include MG-J3 (Eoguttulina), MG-K (Lenticulina), MG-G (Reinholdella), and MG-H (Spirillina). The agglutinated taxa of MG-C (mainly Ammobaculites and Reophax) and MG-D (Trochammina) increase in this stratigraphic interval, respectively reaching $20 \%$ and $9 \%$ (Fig. 7). Diversity and abundance decrease with respect to the top of the Pliensbachian. Epifaunal forms display a slight increase largely represented by Spirillina, Trochammina, and Reinholdella.

The main faunal changes involve the dark marls (top of the Polymorphum Zone and lower part of the Serpentinum Zone; Figs. 7-10). The top of the Polymorphum Zone shows increasing values of MG-K and MG-G, with decreasing proportions of MG-C, MG-D, and MG-H (Fig. 7). The base of the Serpentinum Zone, corresponding to the thin-laminated dark marls, presents abrupt changes in the foraminiferal assemblages. The abundance of foraminifera (specimens per $100 \mathrm{~g}), \alpha$ diversity, and mean size of specimens decrease (Figs. 7-9), except for the genus Lenticulina. The dominant morphogroup is MG-J1 (mainly small specimens of Dentalina and Marginulina), with a peak at the beginning of the Serpentinum Zone (from $65 \%$ to $68 \%$ of the assemblage) coincident with a drop in $\mathrm{CaCO}_{3}$ content and $\delta^{18} \mathrm{O}$, as well as an increase in Mo/Al (Figs. 4 and 7). After that, proportions of MG-J1 show an abrupt decrease to less than $30 \%$ of the assemblage. The MG-J3, represented by small specimens of Eoguttulina, gives high values (from $20 \%$ to $29 \%$ ) at the base of the Serpentinum Zone (Figs. 7 and 8). Other forms reaching high values at the beginning of the Serpentinum Zone are Lenticulina (MG-K), Bolivina (MG-J4), and Reinholdella (MG-G). The MG-D (represented mainly 


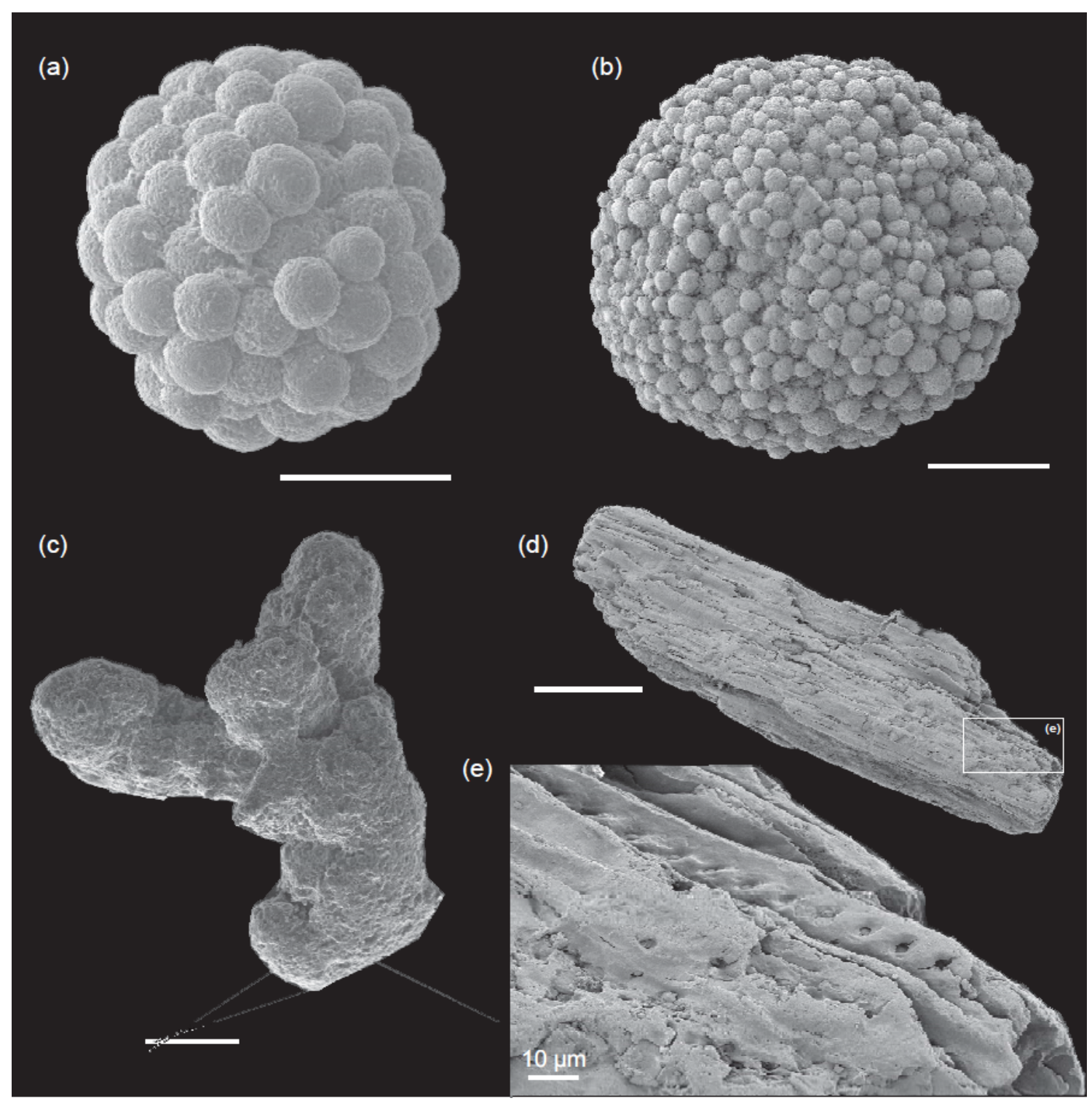

Figure 5. SEM images of mineralizations retrieved from the sieved samples of the thin-laminated dark marls. (a, b) Pyrite framboids. (c) Concretion of Mn oxy-hydroxide. (d, e) Coal wood fragment with preserved tracheid inner cavities and pit pores observed in the detailed view. Scale bar: $100 \mu \mathrm{m}$.

by Trochammina) disappears (Fig. 7). Opportunist forms increase at the base of the Serpentinum Zone, most of them corresponding to potential deep infauna (Lenticulina and Eoguttulina; Rita et al., 2016; Józsa et al., 2018; Reolid et al., 2019a, b; Figs. 8 and 10). These abrupt changes culminate with a barren interval where microfossils are not recorded. This interval is located in the lower part of the thin-laminated dark marls and occurs just after the peak of Mo/Al and TOC (Figs. 4, 8, and 9).

The foraminiferal assemblages are subsequently recovered in the record of genera belonging to MG-J1 (ranging from 20\%-73\%), mainly Dentalina and Nodosaria, with an upward increase in Paralingulina (Figs. 7 and 9). Just after the barren interval some groups present peaks with high abundance (foraminifera per $100 \mathrm{~g}$ ) and proportions, such as Textularia $(38 \%)$ and Lenticulina (28\%). The MG-J3, MG-J4, MG-D, and MG-H do not recover after the barren interval (Fig. 7). Other foraminifera proliferate $1.5 \mathrm{~m}$ above the barren interval, with Paralingulina, Nodosaria, and Dentalina being commonly recorded. After the barren interval the abundance of foraminifera in the $<200 \mu \mathrm{m}$ fraction abruptly increases, most of them $<100 \mu \mathrm{m}$. Foraminifera $>200 \mu \mathrm{m}$ are nearly absent after the barren interval. The number of genera increases after the thin-laminated dark marls, though the $\alpha$ diversity levels at the top of the Pliensbachian are not maintained. The assemblages of foraminifera stabilize just be- 


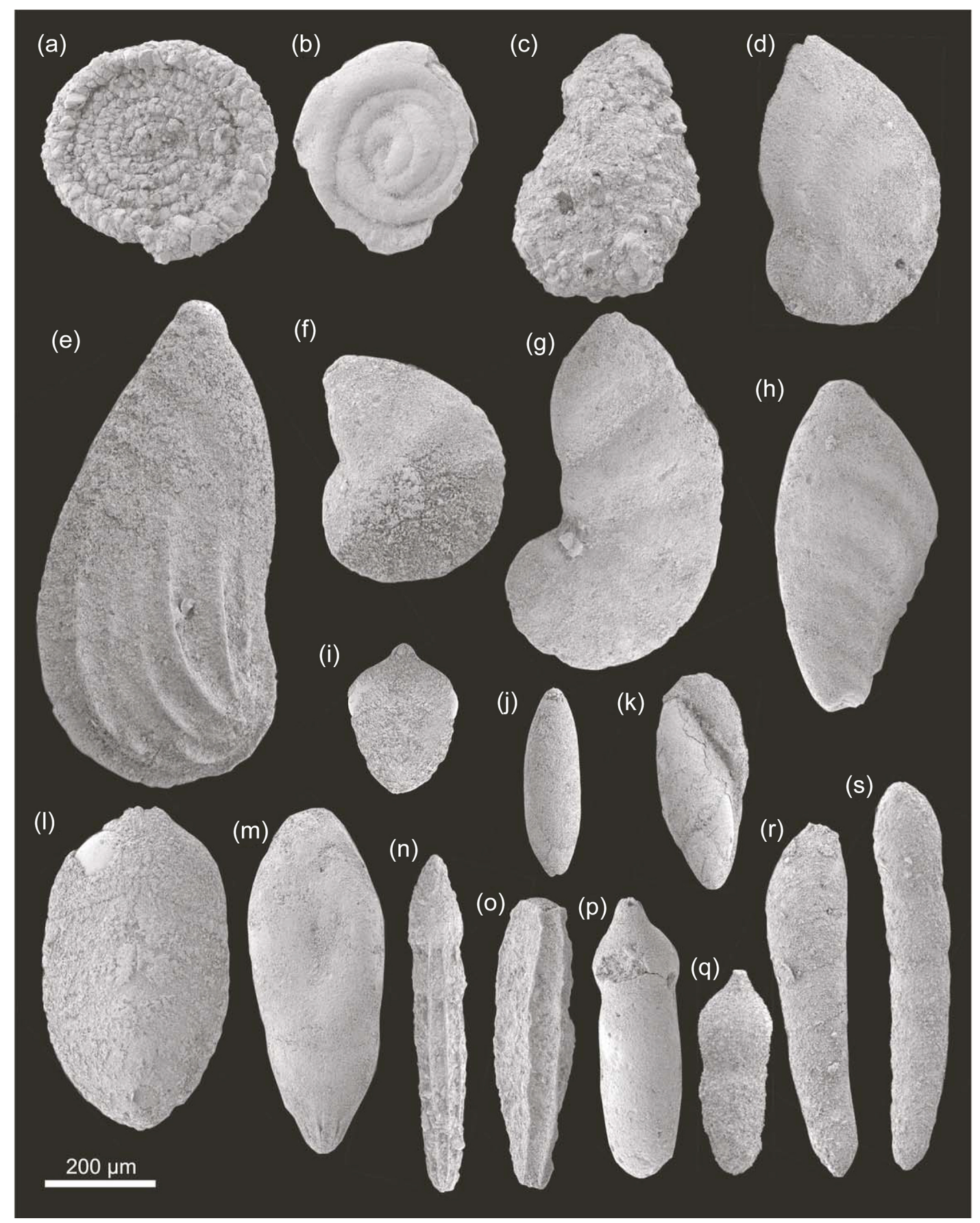

Figure 6. SEM images of benthic foraminifera from the Cueva del Agua section. (a) Ammodiscus. (b) Glomospira. (c) Ammobaculites. (d) Astacolus. (e) Planularia. (f) Lenticulina. (g) Marginulinopsis. (h) Vaginulinopsis. (i) Pseudonodosaria. (j, k) Eoguttulina. (l) Tristix. (m) Pseudonodosaria. (n) Nodosaria. (o) Paralingulina. (p, q) Pseudonodosaria. (r, s) Dentalina.

low the thin-bedded limestones, with a dominance of MG-J1 (mainly Paralingulina and Pseudonodosaria) and increasing values of MG-J3 (Eoguttulina) (Figs. 7 and 9). Shallow infaunal forms prevail, mainly uniserial specialists (Fig. 10).

\subsection{Ostracod assemblages}

The ostracod carapaces are usually well-preserved and articulated (Fig. 11). Only some specimens show recrystallization. The ostracods in the upper part of the Pliensbachian are dominated by the family Bairdiidae (Bairdia, Bairdiacypris, and Isobythocypris), the family Healdiidae (mainly 


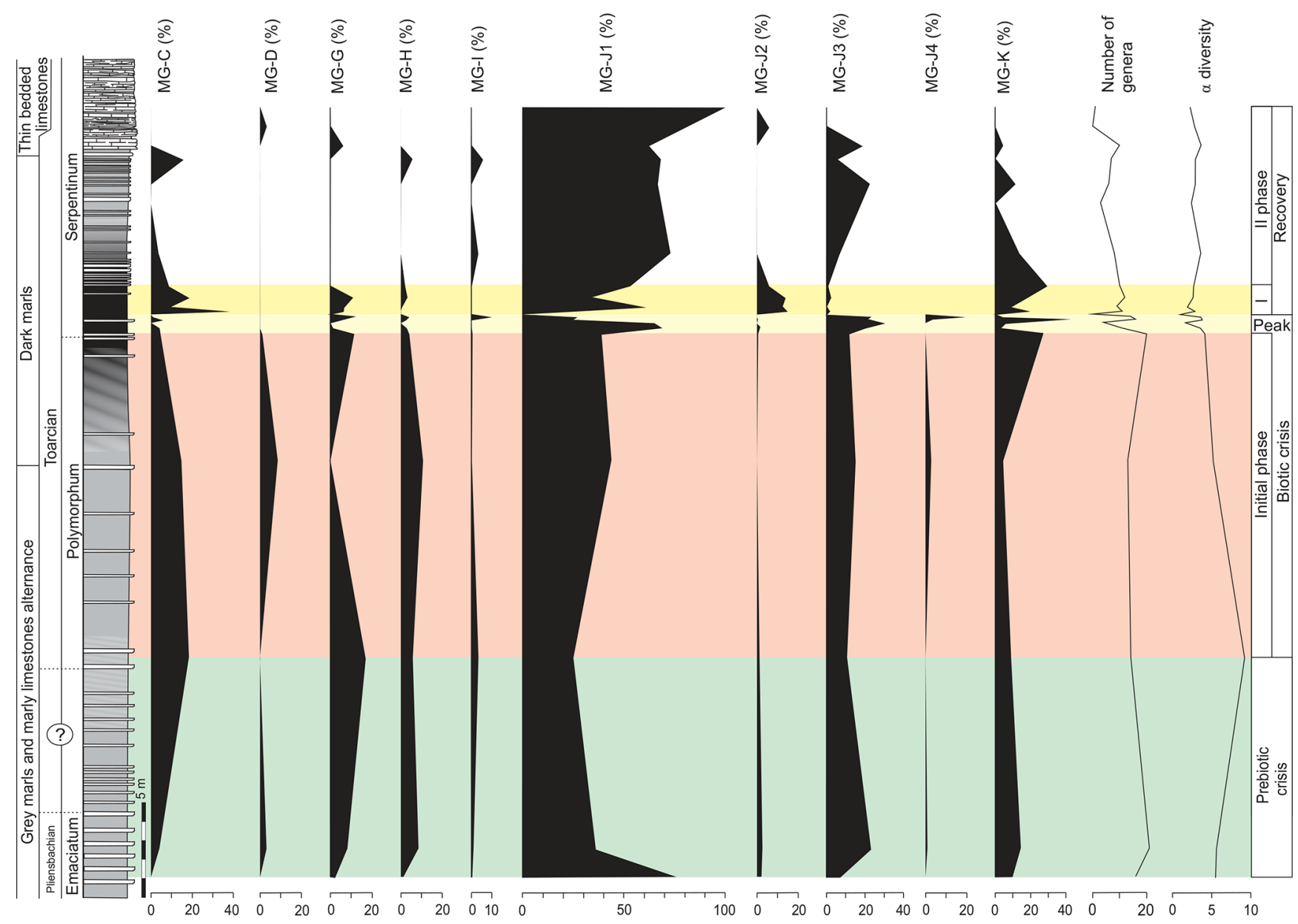

Figure 7. Stratigraphic distribution of the proportions of foraminiferal morphogroups and diversity (number of genera and $\alpha$ diversity).

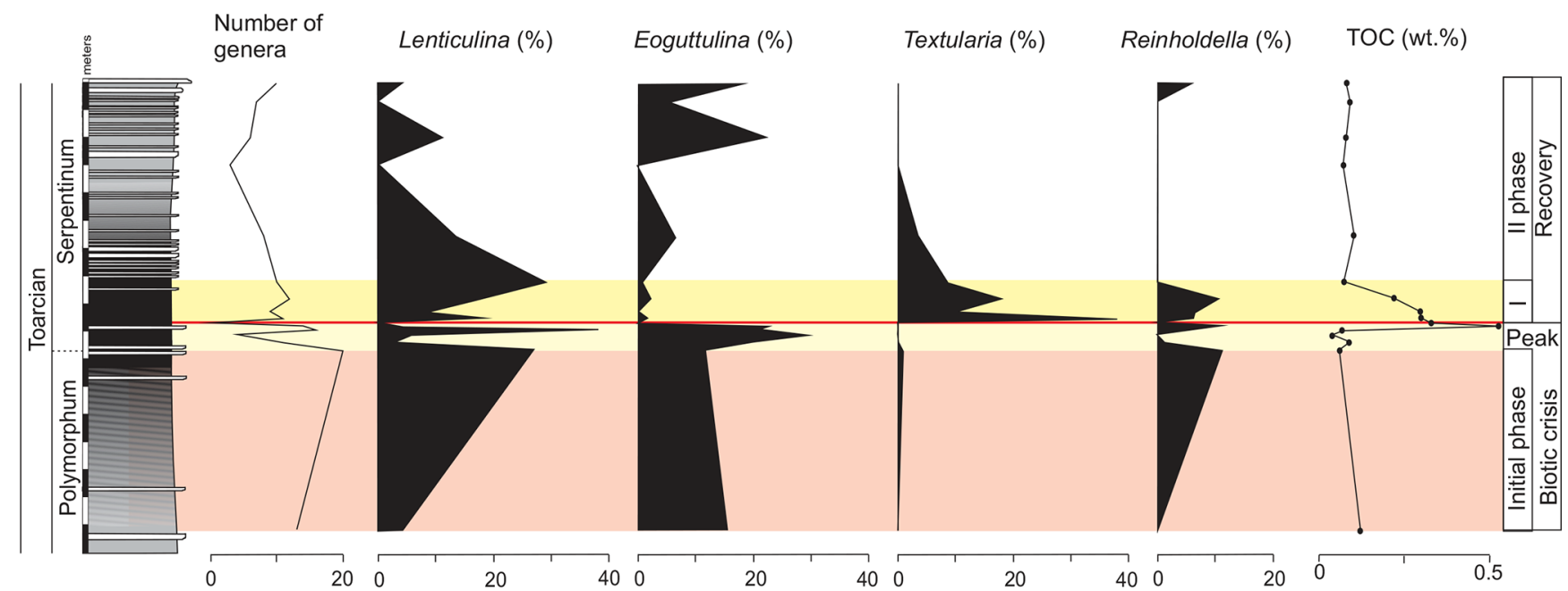

Figure 8. Stratigraphic distribution of the proportions of selected genera of foraminifera in the Polymorphum-Serpentinum Zone boundary compared with diversity and TOC values. 


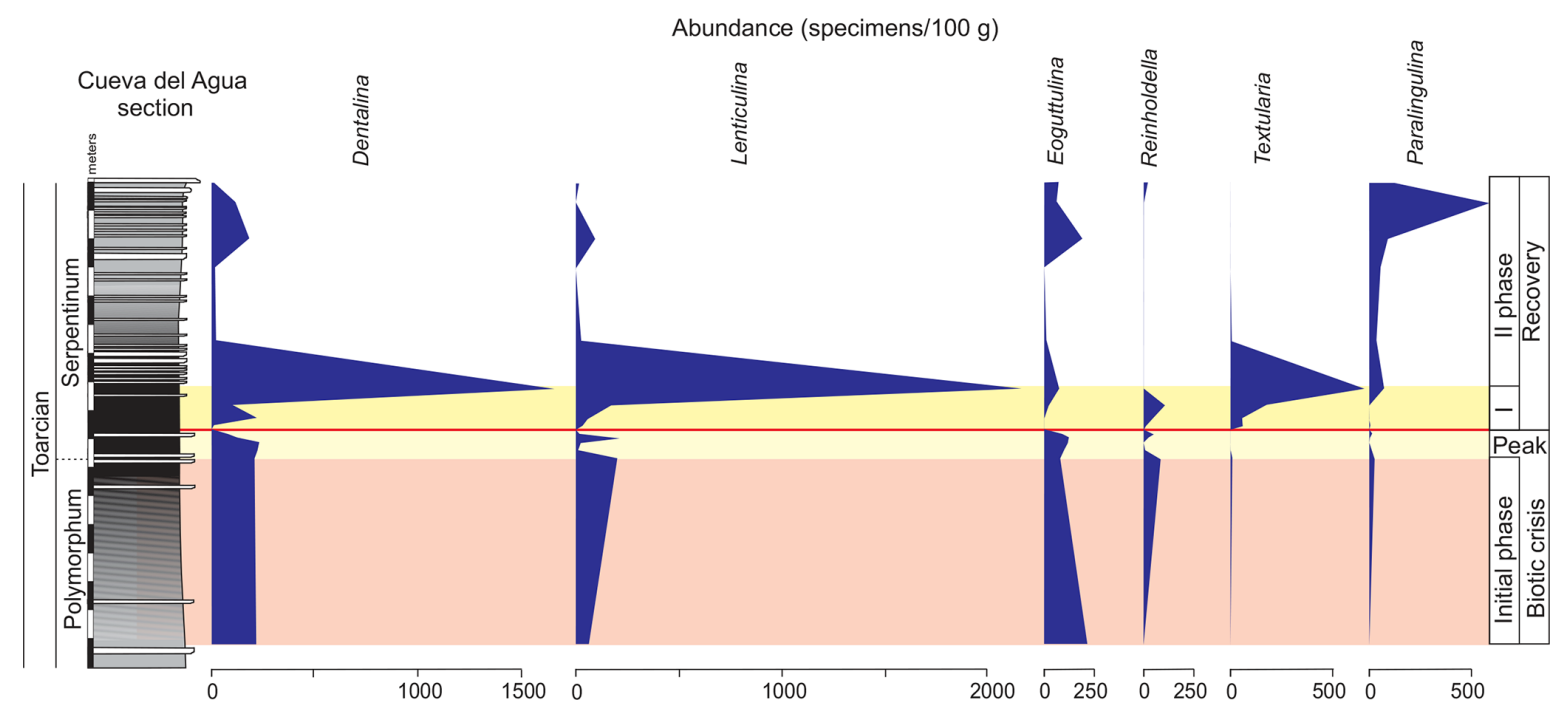

Figure 9. Stratigraphic distribution of the abundance of selected genera of foraminifera in the Polymorphum-Serpentinum Zone boundary.

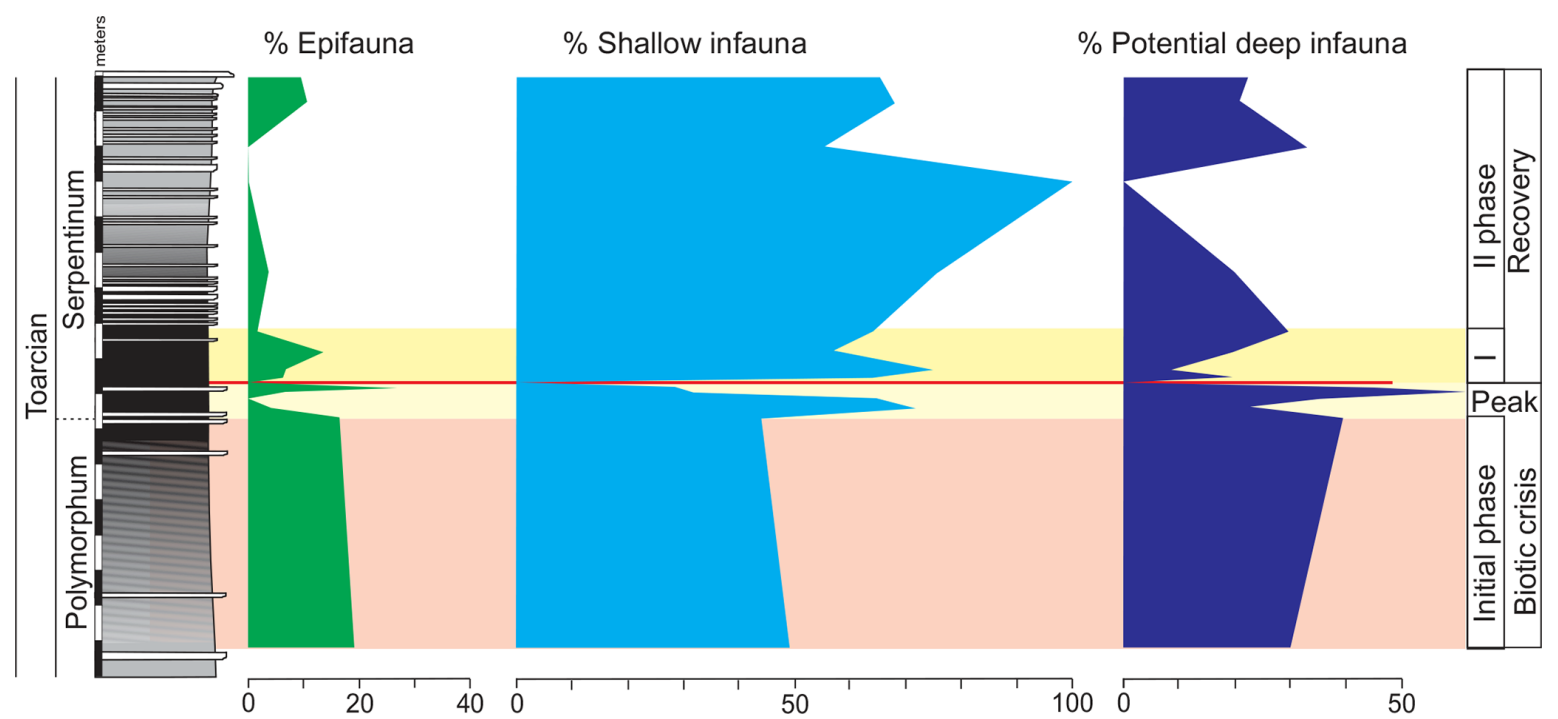

Figure 10. Stratigraphic distribution of the proportions of foraminifera according to lifestyle assigned in the morphogroups (see Fig. 3).

Ogmoconcha), and the family Cyprididae (mainly Liasina lanceolata) (Fig. 12). A total of 12 species were recorded in the uppermost part of the Emaciatum Zone. The Polymorphum Zone (lower Toarcian) shows high values of the family Cyprididae (genus Liasina) and the family Healdiidae (Fig. 12). Only six species of ostracods were recorded in the lower part of the Polymorphum Zone. Ostracods are less abundant in the Polymorphum Zone than at the top of the Pliensbachian, as occurs with foraminifera.

In the upper part of the Polymorphum Zone, corresponding to the dark marls, Pontocyprididae and Bythocytheridae disappear, whereas the family Cytherellidae (Cytherella toarcensis) increases and constitutes the dominant group, followed by Bairdiidae (Bairdia and Ptychobairdia). At the on- set of the Serpentinum Zone (dark marls before the barren interval) there is an increase in Healdiidae, and Polycopidae appear (Fig. 13). In the last sample before the barren benthic horizon only two species are recorded, mainly Cytherella toarcensis and secondarily Ogmoconchella aequalis.

Just above the barren benthic horizon the ostracod assemblage of the lower part of the Serpentinum Zone is characterized by the dominance of the family Cytherellidae and secondarily Cyprididae (Liasina lanceolata) and Bairdiidae (Bairdia sp. and Ptychobairdia hahni) with low $\alpha$ diversity. Families Headiidae, Bythocytheridae, and Polycopidae are not recorded after the barren interval in the Cueva del Agua section (Fig. 13). 


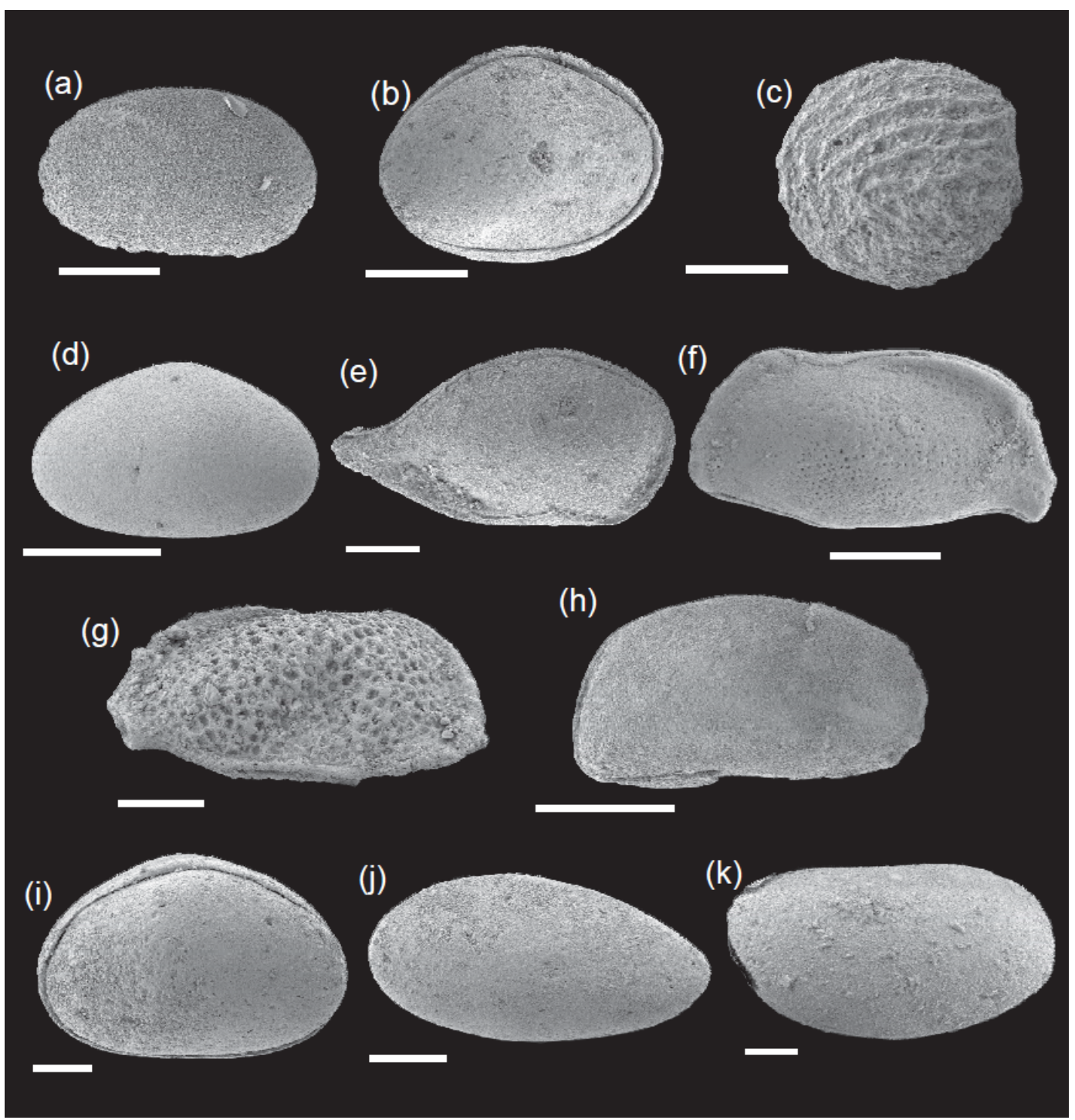

Figure 11. SEM images of ostracods. (a) Ogmoconchella. (b) Ogmoconcha. (c) Polycope. (d) Bairdiacypris. (e) Bairdia. (f, g) Ptychobairdia. (h) Pontocyprella. (i) Cytherella. (j) Liassina. (k) Isobythocypris. Scale bar: $100 \mu \mathrm{m}$.

The abundance of ostracods increases after the thinlaminated dark marls (Fig. 14), constituted mainly by Cytherella toarcensis ( $86 \%$ ), but Cyprididae progressively disappear from this first phase of recovery (Fig. 13). Toward the base of the thin-bedded limestones, the ostracod assemblages are progressively more diverse but dominated by Bairdioidea (family Bairdiidae, mainly Ptychobairdia) and Cytherelloidea (mostly family Cytherellidae; Fig. 13), along with the record of Pontocyprididae and Cyprididae. The base of the thin-bedded limestones shows a further reduction in $\alpha$ diversity.

\subsection{Other microfossils and bioclasts}

Ferruginous moulds of gastropods $(<1 \mathrm{~mm})$ are recorded in the dark marls (Fig. 14). They are composed of haematite, although microstructural analysis under SEM indicates that they were originally cubic and octahedral crystals of pyrite. The ferruginous moulds of the microgastropods are very abundant just above the thin-laminated dark marls (Fig. 15).

Other remains correspond to radiolarians (Fig. 14). They are scarce and preserved as pyrite moulds in the thinlaminated dark marls. This kind of preservation is described for other sections from the Toarcian of the External Subbetic by Reolid (2014b) and Rodrigues et al. (2019). The radiolarians abruptly increase after the thin-laminated dark marls just below the thin-bedded limestones but are preserved as calcite moulds (Fig. 15).

Other remains belong to holothurian sclerites (including synaptid anchor plates of Priscopedatus and chiridotid ossicles of Theelia), thin spines, and plates of echinoids and ophi- 


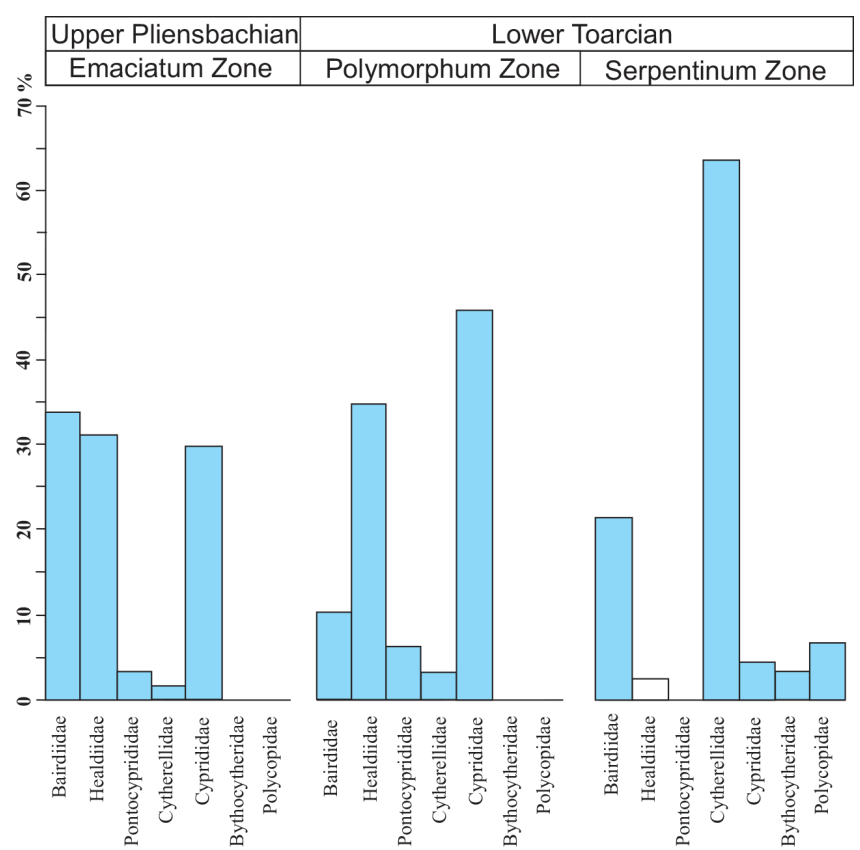

Figure 12. Average composition of ostracod assemblages according to families for the Emaciatum, Polymorphum, and Serpentinum zones. Note that the family Healdiidae in the Serpentinum Zone (white bar) corresponds to specimens prior to the global extinction of this family during the Jenkyns Event.

uroids (arm vertebrae). The spines of echinoids are very thin and abundant in the Serpentinum Zone. They are recorded in the thin-laminated dark marls before the barren benthic horizon, but the maximum abundance is reached some centimetres over the negative CIE in the dark marls. The fragments of holothurians and ophiuroids are especially common just after the barren benthic horizon. In addition, elongated coal (wood) fragments were retrieved from sieved samples. Some coal fragments show tracheid walls to be residual and preserved as lignite; some are well-preserved, showing the tracheid inner cavities with pit pores (Fig. $5 \mathrm{~d}$ and e).

\section{Interpretation}

\subsection{Interpretation of facies and microfacies}

The Zegrí Formation is integrated within the sedimentary sequence II of García-Hernández et al. (1989), limited at the base by the intra-Pliensbachian discontinuity and at the top by the end-Bathonian discontinuity. This sedimentary cycle coincides with the main phase of intracontinental fragmentation (rifting) developed from the late PliensbachianBathonian (see Reolid et al., 2018). The bottom topography of the basin would be irregular with different semigrabens and variable subsidence (Vera, 2001; Nieto et al., 2004; Reolid et al., 2015), as observed in other Tethyan Alpine do- mains (e.g. Jenkyns, 1988; Graciansky et al., 1998; Soussi and Ben Ismail, 2000; Marok and Reolid, 2012).

The alternation of grey marls and marly limestones of the Zegrí Formation represents a pelagic environment, according to the record of ammonites and radiolarians. However, there is continental input evidenced by the terrigenous content of (exclusively) clay minerals, as reported for other areas of the Subbetic (Palomo, 1987; Rodríguez-Tovar and Reolid, 2013) and the record of millimetric coal (wood) fragments (Fig. 5d). The beginning of the Toarcian in the Cueva del Agua section is characterized by decreasing carbonate content (Fig. 4) related to topographic changes at the sea bottom, with the development of troughs and swells (Vera, 2001; Reolid et al., 2015, 2018), in addition to the transgressive regional and global context (e.g. Hallam, 1987; Jenkyns, 1988; Graciansky et al., 1998; Wignall et al., 2005; Korte and Hesselbo, 2011; Haq, 2018; Storm et al., 2020). Some of the troughs in the Subbetic are dominated during the Toarcian by thick marly successions, like those of the Cueva del Agua section, whereas swells are dominated by condensed calcareous successions (Reolid et al., 2015, 2018).

In the Cueva del Agua section, the abrupt decrease in the $\mathrm{CaCO}_{3}$ content and the negative CIE when thin-laminated dark marls are recorded (Fig. 4) are well-correlated with the $\mathrm{T}-\mathrm{OAE}$ and the perturbation of the carbon cycle, as well as the carbonate production located in the lower part of the Serpentinum Zone (Erba, 2004; Mattioli et al., 2004, 2008; Tremolada et al., 2005; Wignall et al., 2005; Hermoso et al., 2009; Suan et al., 2010; Ruebsam et al., 2020a). In the Cueva del Agua section, values of $\mathrm{CaCO}_{3}$ and $\delta^{13} \mathrm{C}$ equivalent to those of the Pliensbachian are not recorded until the thinbedded limestones.

Above the thin-laminated dark marls, the first limestone beds recorded mark an upward increase in carbonate content, ending in the thin-bedded limestones. This first interval of limestones prior to thin-bedded limestones shows hummocky cross-stratification (HCS) structures that signal the input of sediment from shallower areas, yet still below the fairweather wave base, and an increase in oxygenation. Cheel and Leckie (1993) proposed that HCS forms when storm waves reach the sea bottom at maximum depths from 125 to $200 \mathrm{~m}$. These beds are precursors of the thin-bedded limestones that represent the main change in the environmental conditions with respect to the dark marls. The abundance of HCS structures in the thin-bedded limestones indicates enhanced energy conditions at the sea bottom and the input of pelagic sediment from neighbouring areas. Taking into account the extensional tectonic context of the Subbetic (Vera, 2001) and the instability of the bottom, evidenced in other sections by the record of carbonated tempestites, slumps, and breccia in the Zegrí Formation (e.g. Nieto et al., 2004; Reolid et al., 2015), the thin-bedded limestones could be related to the reactivation of tectonic activity and a relative sea-level fall. In addition, the record of the thin-bedded limestone interval might be linked to the intensification of tropical cy- 


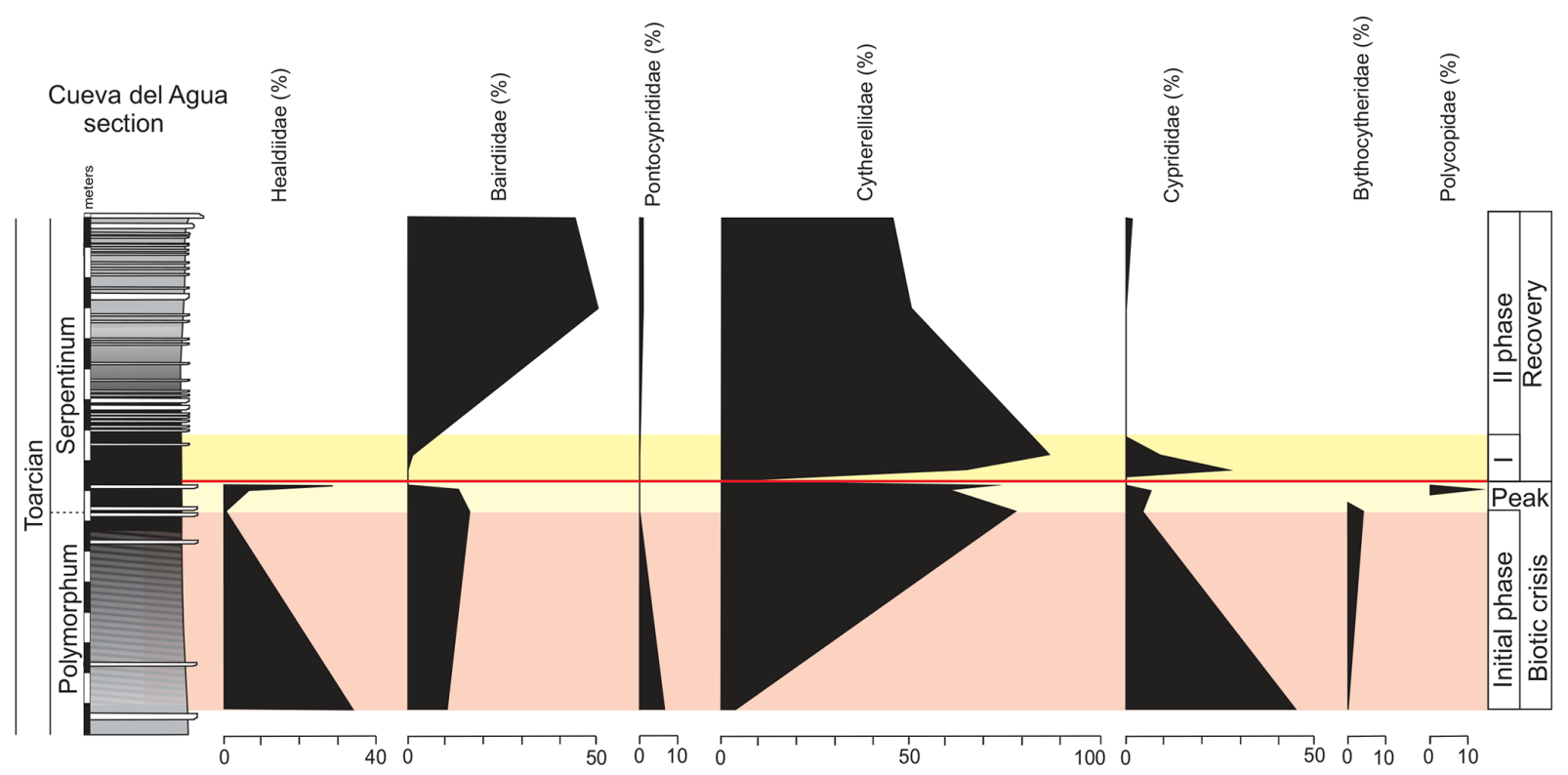

Figure 13. Stratigraphic distribution of the proportion of ostracods in the Polymorphum-Serpentinum Zone boundary.

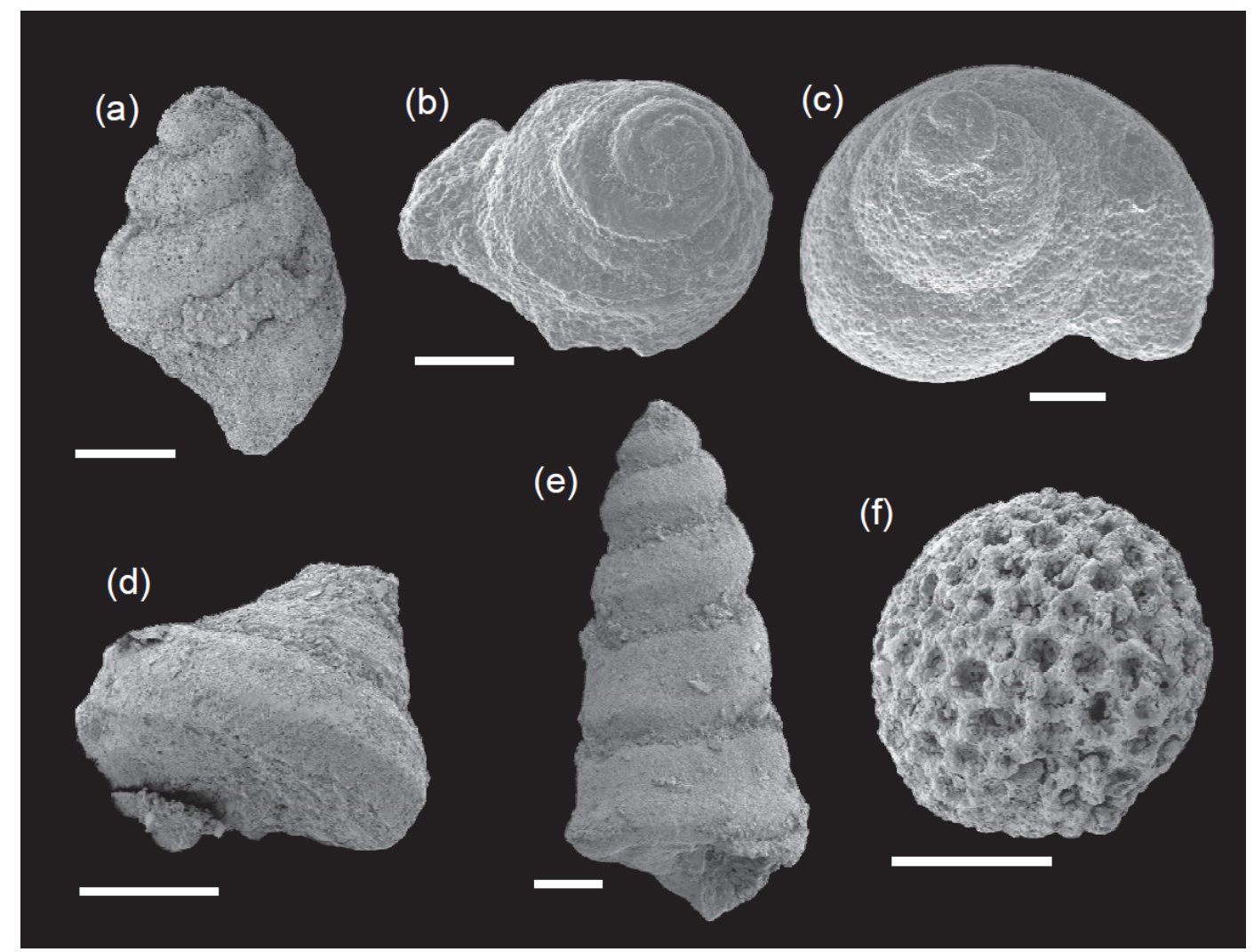

Figure 14. (a-e) Ferruginous moulds of microgastropods. (f) Radiolarian. Scale bar: $100 \mu \mathrm{m}$. 


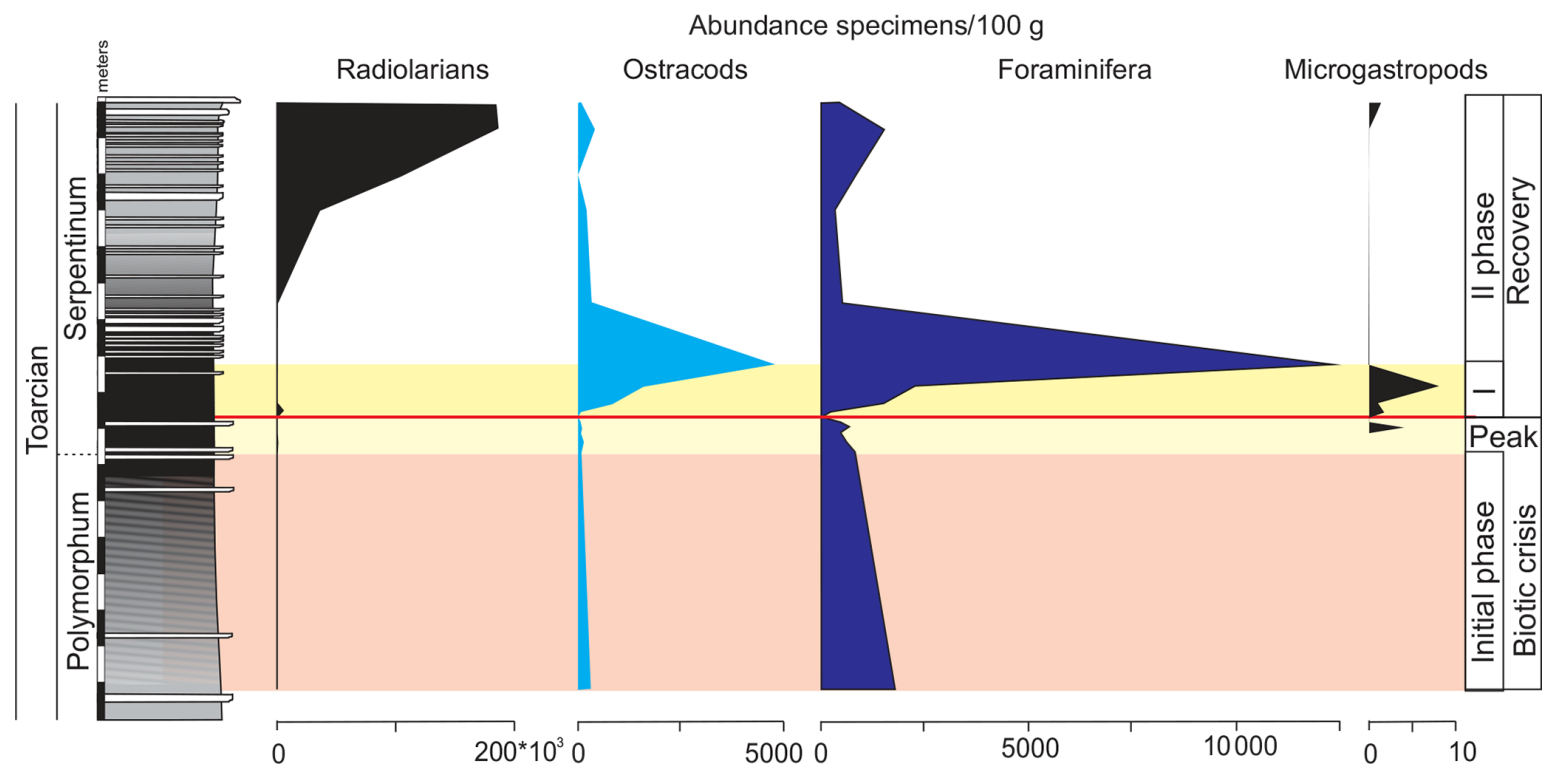

Figure 15. Abundance of radiolarians, ostracods, foraminifera, and ferruginous microgastropods in the studied interval of the Cueva del Agua section.

clones during the lower Toarcian proposed by Krencker et al. (2015). In the Subbetic, the repeated storms enhanced water mixing and eventual re-oxygenation of the bottom waters in the trough areas, as tempestite deposits have been observed in other sections (Reolid et al., 2015, 2020b).

A similar distribution of facies is described for the northern Lusitanian Basin in the Coimbra-Rabaçal region (e.g. Duarte and Soares, 1993; Duarte, 1998; Reolid et al., 2019a). The lower Toarcian in this region corresponds to the Sao Gião Formation. The lower interval is constituted by marly limestones with the Leptaena member followed by thinbedded limestones with the Hildaites member having parallel lamination and cross-lamination. Watkinson (1989) and Duarte (1997) interpreted the thin-bedded limestones as tempestitic-turbiditic deposits, also related to tectonic reactivation (Duarte and Soares, 1993; Duarte, 1997) and enhanced storm activity (Reolid et al., 2019a). This interpretation resembles that of the Cueva del Agua section.

\subsection{Organic matter and sea bottom oxygenation}

Integrated analysis of facies, microfacies, and geochemistry indicates that the main environmental changes occurred in the thin-laminated dark marls (middle part of the dark marls). Within this interval of the Cueva del Agua section, the values of TOC, TS, and the Mo/Al ratio increase, whereas $\delta^{18} \mathrm{O}$ and $\delta^{13} \mathrm{C}$ data show an accentuated decrease (Fig. 4). The maximum values of TOC, TS, and $\mathrm{Mo} / \mathrm{Al}$ coincide with the barren benthic horizon at the base of the Serpentinum Zone, which may correlate with the T-OAE.

The Mo/Al peak (Fig. 4) indicates oxygen-depleted conditions at the seafloor due to the fact that the fixation of the Mo in the sediment implies reducing conditions. The $\mathrm{MoO}_{4}^{2-}$ is precipitated from the water column through the mineralization of organic thiomolibdates and complex groups of $\mathrm{Fe}-$ Mo-S, forming a solid solution with iron sulfides (Helz et al., 1996). Therefore, in marine facies, the relative enrichment of organic matter together with the Mo content point to reducing conditions (e.g. Meyers et al., 2005; Tribovillard et al., 2006; Algeo et al., 2012; Aguado et al., 2016; Reolid et al., 2016; Zhang et al., 2017; Ruebsam et al., 2020b). An increased Mo/Al ratio in the Serpentinum Zone has been identified during the Jenkyns Event in other sections of the External Subbetic (Rodríguez-Tovar and Reolid, 2013; Reolid, 2014a), the Saharan Atlas (Algeria; Reolid et al., 2012a; Ruebsam et al., 2020b), the Lusitanian Basin (Portugal; Reolid et al., 2019a), and the eastern Paris Basin (Lezin et al., 2013), associated with stratigraphic intervals evidencing a biotic crisis in terms of benthic faunas. The record of pyrite framboids is congruent with reducing conditions, even in the sediment pore water.

The oxygen-depleted conditions are compatible with increased TOC values (from $0.20 \%$ to $0.53 \%$ ) of the thinlaminated dark marls (Fig. 4), though these are low values if compared with central and northern European outcrops. Thus, for the Serpentinum Zone (Levisoni Zone for Mediterranean biozonation and Falciferum Zone for sub-boreal biozonation), the TOC values range from $5 \%$ to $15 \%$ in the outcrops of northern Europe (Sælen et al., 2000; Röhl et al., 2001; Bucefalo-Palliani et al., 2002; Mailliot et al., 2006; McArthur et al., 2008; Baroni et al., 2018; Thibault et al., 2018; Fantasia et al., 2019; among others), whereas in the Tethys region (southern Europe and North Africa) the values range from $0.5 \%$ to $3 \%$ (Jenkyns, 1985, 1988; Jenkyns 
et al., 2002; Hesselbo et al., 2007; Bodin et al., 2010; Reolid et al., 2012b; Rodrigues et al., 2019; Ruebsam et al., 2020a, b; among others). This stands as evidence of the geographic variations of the T-OAE signal (see also Hermoso et al., 2009; Ruebsam et al., 2020b). The thin-laminated dark marls registered during the organic-matter-rich intervals of the T-OAE, similar to the ones recorded in the Cueva del Agua section, are likewise reported for the T-OAE elsewhere (Parisi et al., 1996; Röhl et al., 2001; Hermoso et al., 2009; Izumi et al., 2012, among others).

In recent marine environments there is a positive relation between TOC and $\mathrm{S}$ coming from pyrite (Berner and Raiswell, 1983), which is formed through the reaction of $\mathrm{H}_{2} \mathrm{~S}$ generated by sulfate-reducing bacteria (SRB) in anoxic environments with $\mathrm{Fe}$. The increased TS in the thin-laminated dark marls is congruent with the greater TOC values and the depleted oxygen conditions indicated by the Mo/Al ratio. Caswell and Coe (2012) and Ruebsam et al. (2020b) showed a parallel increase in TOC and TS in the Levisoni-Falciferum Zone (Serpentinum Zone) from deposits of the East Midlands Shelf (UK) and Atlasic Basin of Algeria, respectively.

Above the thin-laminated dark marls interval, Mo/Al, TOC, and TS decrease at the same time that benthic microfossils and trace fossils are recorded. The record of ferruginized moulds of microgastropods is common from sieved samples, which is compatible with the early phases of sea bottom recolonization described in further contexts (Suan et al., 2013; Teichert and Nutzel, 2014; Gatto et al., 2015). The haematite composition of the microgastropod moulds is indicative of an oxidation front, further favouring the precipitation of Mn oxides and oxy-hydroxides in the sediment-water interface due to oxygen availability (Thomson et al., 1999; Powell et al., 2003). Even though the presence of haematite moulds must be related to oxygen availability at the sea bottom, the diagenetic history of these moulds remains complex. The microtextural features of the haematite forming the moulds evidence an original composition as pyrite in the initial infilling of the gastropod shell. This pyrite precipitated before the dissolution of the aragonitic shell during the early diagenesis, followed by reducing conditions in the sediment pore water. The subsequent advance within the sediment pore water of the oxygenation favoured the precipitation of $\mathrm{Fe}$ and Mn oxides and oxy-hydroxides, as well as the transformation of gastropod pyrite moulds to haematite. The return to oxic conditions and the potential advance within the sediment of the oxic front (evidenced by the ferruginous moulds of gastropods and small Mn concretions) could also favour the oxidation of organic matter and the remobilization of sulfur.

\subsection{Isotopic fluctuations and environmental changes}

In the Cueva del Agua section, the $\delta^{13} \mathrm{C}$ values show a pronounced decrease of $0.84 \%$ from the base of the thinlaminated dark marl interval coinciding with the drop in $\mathrm{CaCO}_{3}$ wt \% (base of the Serpentinum Zone). These fluctu- ations are related to the perturbation of the carbon cycle associated with the Jenkyns Event and can be linked to other processes such as sea-level rise, global warming, seawater acidification, and deoxygenation of the bottom seawater (see Dera and Donnadieu, 2012; Reolid et al., 2014a; Casellato and Erba, 2015; Müller et al., 2020; Storm et al., 2020) that affected marine biota and carbonate productivity. The negative CIE was recorded both in carbonates and organic matter in other sections of the South Iberian Palaeomargin represented in the Subbetic, such as Fuente Vidriera (Reolid, 2014a; Rodrigues et al., 2019) and La Cerradura sections (Reolid et al., 2014a; Rodrigues et al., 2019; Ruebsam et al., 2020a). No $\delta^{13} \mathrm{C}$ values similar to those of the Pliensbachian are recorded in the Cueva del Agua section until the thinbedded limestones (upper part of Serpentinum Zone).

The original signal of $\delta^{18} \mathrm{O}$ was surely affected by carbonate mobilization in these sediments, as evidenced by the recrystallization of some microfossils, for which reason absolute values should be regarded with caution. Still, the $\delta^{18} \mathrm{O}$ values for the lower Toarcian are within the range reported in previous works (Dera et al., 2009), around -3\%o in the Polymorphum Zone, showing a pronounced decrease at the base of the Serpentinum Zone in the thin-laminated dark marls $(-5.36 \%$ to $-4.95 \%$ ) . These data are very close to those reported by Gómez and Goy (2011) for $\delta^{18} \mathrm{O}$ from bulk samples of sections in Rodiles Oeste (Basque-Cantabrian Basin, northern Spain) and Sierra Palomera (Iberian Range, eastern Spain). The above authors report a negative excursion at the base of the Serpentinum Zone (from $-3.0 \%$ o to $-5.5 \%$ ). Other European sections also underline this negative isotopic excursion with $\delta^{18} \mathrm{O}$ values obtained from bulk samples, belemnites, and brachiopods (Anderson and Arthur, 1983; Rohl et al., 2001; Jenkyns, 2003; Rosales et al., 2004; Suan et al., 2008, 2010; Harazim et al, 2013). In light of $\delta^{18} \mathrm{O}$ values, Rosales et al. (2004) and Gómez and Goy (2011) interpreted a palaeotemperature of $24^{\circ} \mathrm{C}$ during the late Pliensbachian and the Polymorphum Zone, with an abrupt increase to $32^{\circ} \mathrm{C}$ at the base of the Serpentinum Zone for Iberian palaeomargins. Ruebsam et al. (2020a) infer from $\delta^{13} \mathrm{C}$ values from different organic molecules of the External Subbetic that the early Toarcian warming was paralleled by an increase in atmospheric $\mathrm{CO}_{2}$ levels from $\sim 500$ to $\sim 1000$ ppmv. Molecular palaeothermometry based on the TEX86 proxy indicates that the sea surface temperature in the Subbetic varied from 22 to $32^{\circ} \mathrm{C}$ during the Jenkyns Event (Ruebsam et al., 2020c). According to Rodrigues et al. (2019) and Ruebsam et al. (2020a), the climatic belts in the South Iberian Palaeomargin suffered a displacement to the north, turning more arid in this area of the Western Tethys.

\subsection{Record of the biotic crisis on microfossil assemblages}

Different environmental changes may be interpreted from the fluctuations in microfossil assemblages, mainly foraminifera. 
These fluctuations correlate with those from the facies and geochemistry.

\subsubsection{Prebiotic crisis}

Despite the few stratigraphic levels investigated for benthic foraminifera at the top of the Pliensbachian and the beginning of the Toarcian (Polymorphum Zone), it seems like it is characterized by high $\alpha$ diversity of foraminifera and the dominance of specialists. Such an assemblage is typical of this time interval in the basins of the Western Tethys (e.g. Reolid et al., 2013, 2014b; Rita et al., 2016). The forms are mainly uniserial (MG-J1), like Dentalina and Nodosaria, as occurs in the studied section (Fig. 7). The dominance of shallow infauna and the record of potential deep infauna such as Eoguttulina (MG-J3) and Lenticulina (MG-K) indicate good tiering as well as unrestricted trophic resources and oxygen availability. The same good tiering for foraminiferal assemblages is reported for the top of the Pliensbachian in the Lusitanian Basin (Rita et al., 2016; Reolid et al., 2019a), the Basque-Cantabrian Basin (Herrero, 1998), Cardigan Bay Basin (Reolid et al., 2019b), Atlasic Basin (Reolid et al., 2012b, 2013), and Umbria-Marche Basin (Bartolini et al., 1992), among others. The ostracods in the upper part of the Pliensbachian are also diverse in the Cueva del Agua section, and the record of bioclasts of other benthic organisms - echinoid, ophiuroid, and holothurian plates - confirms the favourable conditions at the seafloor.

\subsubsection{Initial phase of the biotic crisis}

The abundance and $\alpha$ diversity of foraminifera in the Polymorphum Zone of the Cueva del Agua section decrease with respect to the top of the Pliensbachian, as observed at the Yorkshire coast (Hylton, 2000), Mochras borehole (Wales; Reolid et al., 2019b), the Peniche and Maria Pares sections (Portugal; Rita et al., 2016; Reolid et al., 2019a), and the Ratnek El Kahla section (Algeria; Reolid et al., 2012b). Epifaunal forms such as Reinholdella, Trochammina, and Spirillina increase near the top of the Polymorphum. Decreased abundance and $\alpha$ diversity together with an increase in epifauna are interpreted as related to the prebiotic crisis and destabilization of environmental conditions at the seafloor. In southern Germany (Riegraf, 1985; Hylton, 2000), the Cardigan Bay Basin (Copestake and Johnson, 2014; Reolid et al., 2019a), and the Iberian Range (Herrero, 1994), numerous taxa became extinct in the Polymorphum Zone and at the Polymorphum-Levisoni boundary.

The ostracod assemblages at the top of the Polymorphum Zone show less $\alpha$ diversity and abundance as well as a change in the composition of the assemblage, dominated by forms of the family Bairdiidae and Cytherellidae (mainly Cytherella). Cytherella has been interpreted as indicative of warm waters (Peypouquet et al., 1981; Depêche, 1984; Whatley, 1995; Bonnet et al., 1999; N'Zaba-Makaya et al., 2003). Cytherel- lids are more resistant than other ostracods when oxygenation drops to critical levels (Whatley, 1991, 1995). Cytherella is an infaunal ostracod that can survive low oxygen episodes by adapting its metabolism to require less oxygen. The identification of large numbers of cytherellids has been associated with low oxygen levels in the Toarcian (Boomer and Whatley, 1992; Whatley et al., 1994; Arias and Whatley, 2004; Boomer et al., 2008). Corbari (2004) observed that Cytherella cf. abyssorum is less active than other ostracods when hypoxic conditions are established. In addition, the thickness of the valves serves as a temporal barrier to diffuse toxic substances, such as $\mathrm{CO}_{2}$ partial pressure and $\mathrm{H}_{2} \mathrm{~S}$ concentrations, when the redox boundary is shallower in the sediment (Corbari, 2004). Some studies correlate oxygenation with the percentage of Cytherellidae (Lethiers and Whatley, 1994, 1995; Whatley, 1995; Whatley et al., 2003). In this sense, the increase in Cytherella in the upper part of the Polymorphum Zone is interpreted as related to a progressive decrease in oxygenation within the sediment. Corbari et al. (2004) and Corbari (2004) proposed that Platycopida (Cytherellidae) could remain in the deep layer of sediment for longer periods, whereas other Podocopida (such as Bairdiidae and Pontocyprididae) would have to rise to the surface, where they are subjected to higher predation.

\subsubsection{Peak of the biotic crisis}

The microfossil assemblages of the lowermost part of the Serpentinum Zone, corresponding to the thin-laminated dark marls, present abrupt changes (Figs. 9 and 12). In the case of foraminifera, the abundance, $\alpha$ diversity, and mean size of specimens decrease (from 170 to $136 \mu \mathrm{m}$ ). The dominant morphogroup is MG-J1 (mainly small specimens of Dentalina and Marginulina, mean size $127 \mu \mathrm{m}$ ), which presents a peak at the beginning of the Serpentinum Zone (Fig. 7) coincident with the decrease in $\mathrm{CaCO}_{3}$ content and $\delta^{18} \mathrm{O}$, as well as the increase in $\mathrm{Mo} / \mathrm{Al}$ (Fig. 4). After that, proportions of MG-J1 show an abrupt decrease $(<30 \%)$. The MG-J3, represented by small specimens of Eoguttulina, shows high values (from $20 \%$ to $29 \%$ ) at the base of the Serpentinum Zone. Other forms reaching high values at the onset of the Serpentinum Zone are Lenticulina, Bolivina, and Reinholdella. Both Lenticulina and Eoguttulina are interpreted as potential deep infaunal forms with opportunist behaviour (Reolid, 2008; Reolid et al., 2013, 2019a, b; Rita et al., 2016). The genus Reinholdella has been interpreted as an epifaunal opportunist (Hylton, 2000; Clemence et al., 2010; Reolid et al., 2012b, 2019a, b; Rita et al., 2016). An increase in opportunist forms is indicative of progressively unfavourable conditions. The absence of trace fossils and the increase of TOC and Mo/Al point to progressive deoxygenation of the bottom. Forms with high mobility within the sediment (Eoguttulina and Lenticulina) and epifaunal forms (Reinholdella) initially survive stressful conditions. 
The diversity of ostracods decreases in the dark marls of the Serpentinum Zone before the barren horizon, with the disappearance of Bythocytheridae and Pontocypridae, while Polycopidae is first recorded in the Cueva del Agua section (Fig. 13). Polycopidae has been interpreted as a nektonicpelagic form (N'Zaba-Makaya et al., 2003; Corbari, 2004), which is congruent with the transgression that occurred during the T-OAE (Korte and Hesselbo, 2011; Haq, 2018). In the last sample before the barren benthic horizon, only two species have been recorded: mainly Cytherella toarcensis and secondarily Ogmoconchella aequalis. The record of Cytherellidae is compatible with the deoxygenation of the infaunal microhabitat inferred by previous authors (e.g. Whatley et al., 2003; Boomer et al., 2008). Ogmoconcha and $O g$ moconchella are interpreted as tolerant of hypoxic conditions according to Whatley (1995) and N'Zaba-Makaya et al. (2003), also congruent with the record of Ogmoconchella just before the biotic crisis.

These abrupt changes in geochemistry and fauna conclude with a barren benthic horizon where microfossils are not recorded. This horizon is located in the lower part of the thinlaminated dark marls and occurs just after the peak of Mo/Al and TOC (Figs. 4 and 15). A similar barren benthic interval or horizon has been reported in other basins related to the TOAE, such as the Atlas Basin (Ksour Mountains in Algeria; Reolid et al., 2012a), the Lusitanian Basin (Rita et al., 2016; Reolid et al., 2019a), and SE France (Józsa et al., 2018). In other sections of the Tethys with less incidence of oxygenrestricted conditions (T-OAE), the biotic crisis is only represented by decreased abundance, $\alpha$ diversity, and size of foraminifera and ostracods, with a dominance of opportunist forms, but there is no barren benthic interval. Such is the case of the Ait Albegal and Issouka sections from the Middle Atlas (Morocco; Bejjaji et al., 2010; Reolid et al., 2013), Beni Snassen from Rif (northern Morocco; Boudchiche et al., 1987), the Mellala section of Tlemcen domain (Algeria; Reolid et al., 2014b; Soulimane et al., 2017a, b), the Maria Pares section from the north Lusitanian Basin (Portugal; Reolid et al., 2019a), the Muro de Aguas, Moneva, and Ricla sections from the Iberian Range (Spain; Herrero, 1994), the Pont de Suert section of the Pyrenees (Spain; Nicollin et al., 1995), the Quercy section of the Aquitaine Basin (France; Rey et al., 1994), Truc de Balduc (France; Hylton, 2000), the Valdorbia section from Umbria-Marche (Italy; Bartolini et al., 1992; Nocchi and Bartolini, 1994), and the Mochras borehole, Cardigan Bay Basin (western Wales; Reolid et al., 2019b). Therefore, the biotic crisis could be linked not only to oxygen-depleted conditions in the bottom, but also global warming, as the Jenkyns Event is identified as a hyperthermal event (e.g. García Joral et al., 2011; Korte and Hesselbo, 2011; Suan et al., 2011; Danise et al., 2013; Baghli et al., 2020; Storm et al., 2020).

\subsubsection{Recovery phase}

The foraminiferal assemblages are recovered after the barren benthic horizon with the record of specialist forms (mainly Dentalina and Nodosaria with an upward increase in Paralingulina) and opportunist ones (Textularia and Lenticulina; Fig. 9). Lenticulina has been described during the first phases of colonization of the sea bottom after the T-OAE (Reolid et al., 2012a, b). The MG-J3, MG-J4, MG-D, and MG-H are not recovered after the biotic crisis (Fig. 7). The abundance of foraminifera increases, mainly forms $<200 \mu \mathrm{m}$, during an initial phase of the recovery. The ferruginous moulds of the microgastropods are abundant in the thin-laminated dark marls just over the barren benthic horizon (Fig. 15) during the first phase of recovery. The record of numerous small gastropods is compatible with the early stages of seafloor recolonization, as described in further contexts (Suan et al., 2013; Teichert and Nutzel, 2014; Gatto et al., 2015). The proliferation of opportunist organisms of small size (e.g. Lenticulina and gastropods) is an adaptive strategy to unfavourable conditions known as the Lilliput effect (Urbanek, 1993; Twitchett, 2007; Morten and Twitchett, 2009). This strategy consists of a temporary decrease in size among the species in order to survive in confined environments (Urbanek, 1993).

Just above the barren benthic horizon, the ostracod assemblage presents low diversity, while abundance is triggered in the first phase of recovery (Fig. 15). The assemblages are now dominated by the family Cytherellidae (Cytherella toarcensis reaches $86 \%$ ) and secondarily Cyprididae (Liasina lanceolata) and Bairdiidae (Bairdia sp.). The family Bairdiidae is composed of smooth-shelled ostracods that require open-marine conditions and present high palaeoecologic tolerance (Fohrer and Samankassou, 2005). The genus Bairdia is a shallow infaunal to epifaunal form (Sohn, 1960) interpreted as an opportunist (Fohrer and Samankassou, 2005; Reolid, 2014a). Metacopina (Healdiidae) are not recorded after the biotic crisis as widely as in other Tethys localities (Boomer and Whatley, 1992; Whatley et al., 1994; Arias and Whatley, 2004; Boomer et al., 2008; Arias, 2013; Cabral et al., 2013; Soulimane et al., 2017a, 2020). The Jenkyns Event marks the global extinction of Metacopina (e.g. Boomer et al., 2008; Arias, 2013). Families Healdiidae, Bythocytheridae, and Polycopidae are not recovered after the barren interval. The dominance of Cytherella is congruent with its opportunist character and tolerance of low oxygen conditions. Ogmoconcha and Ogmoconchella have also been interpreted as tolerant to hypoxic conditions (Whatley, 1995; N'Zaba-Makaya et al., 2003), but they were most likely affected by global warming conditions, whereas Cytherella can support warm waters (Whatley, 1995; Bonnet et al., 1999; N'Zaba-Makaya et al., 2003). Metabolic oxygen consumption increases with enhanced temperature in many organisms, and hence thermal limits on survival are imposed when it exceeds the capacity for obtaining oxygen from the environment (Pörtner, 2010). This could apply to Healdiidae, 
despite the fact that Ogmoconcha and Ogmoconchella may be tolerant of oxygen-depleted conditions (Whatley, 1995).

Some authors propose that the early Toarcian ostracod turnover is a consequence of global warming (Arias and Whatley, 2004; Gómez and Arias, 2010; Arias, 2013). Boomer et al. (2008) and Arias and Whatley (2009) put forth the possible existence of competition among the different ostracod groups after extinction of the metacopines. Such competition would have resulted in the occupation of niches vacated by other groups, such as opportunist organisms (bairdioids and cytherellids) that could withstand oxygen-poor conditions.

Other colonizers of the seafloor after the barren benthic horizon were holothurians and ophiuroids. Trace fossils, mainly Chondrites and Planolites, are again recorded after the thin-laminated dark marls, thus confirming the increase in oxygenation in the sediment. Other sections in the External Subbetic (Fuente Vidriera and La Cerradura sections) show a similar distribution of trace fossils with a barren benthic horizon in the peak of the negative CIE and recovery just above it (Rodríguez-Tovar and Uchman, 2010; Reolid et al., 2014a).

The assemblages of foraminifera are more diverse and stable right below the thin-bedded limestones, marking the second phase of the recovery after the biotic crisis, with a dominance of infaunal uniserial forms (mainly Paralingulina and Pseudonodosaria) and increasing percentages of Eoguttulina. However, the $\alpha$-diversity values do not reach the values seen at the top of the Pliensbachian. The radiolarians abruptly increase just below the thin-bedded limestones, meaning the hemipelagic influence probably increased.

\section{Conclusions}

This analysis of the Cueva del Agua section, in the External Subbetic (Betic Cordillera), demonstrates the incidence of the Jenkyns Event in the eastern part of the South Iberian Palaeomargin, represented by a deoxygenation episode correlative with the T-OAE. Facies show an abrupt decrease in $\mathrm{CaCO}_{3}$ content and the deposition of dark marls in the Polymorphum-Serpentinum Zone boundary. Right at this boundary, trace fossils disappear and thin-laminated dark marls are recorded together with a negative CIE. Furthermore, TOC, TS, and redox-sensitive elements $(\mathrm{Mo} / \mathrm{Al})$ increase in this facies, pointing to oxygen-depleted conditions during the deposition of the thin-laminated dark marls. The $\delta^{18} \mathrm{O}$ shows an abrupt decrease in the PolymorphumSerpentinum Zone boundary. Such fluctuations are wellcorrelated with the Jenkyns Event, which entails perturbation of the carbon cycle and carbonate production, as well as a global warming recorded in the lower part of the Serpentinum Zone and the T-OAE.

Decreased diversity of foraminifera and ostracods, as well as the abundant specialist forms in the PolymorphumSerpentinum Zone boundary with respect to the top of Pliens- bachian, indicates unfavourable conditions at the sea bottom and hence opportunists (Lenticulina, Eoguttulina, Reinholdella, and Cytherella) just before the negative CIE. These features of environmental instability during the upper part of the Polymorphum Zone can be inferred as the bellwether of the T-OAE, the initial phase of the biotic crisis. The peak of the biotic crisis is characterized by maximum values of TOC (but relatively low $0.53 \mathrm{wt} \%$ ), TS, and $\mathrm{Mo} / \mathrm{Al}$, as well as the record of a barren benthic horizon.

Above the thin-laminated dark marls, TOC, TS, and redox-sensitive elements recover pre-T-OAE values. The foraminifera, ostracods, and trace fossils are progressively more abundant and diverse. The first colonizers of the sea bottom were opportunist foraminifera (Lenticulina and Textularia), opportunist ostracods (Cytherella), microgastropods, and Chondrites trace makers. After the explosion of opportunist forms, the second phase of recovery is characterized by a progressive increase in diversity. These data indicate the progressive environmental improvement of oxygen availability at the sea bottom. The carbonate content increases upwardly above the dark marls, up to the thin-bedded limestones that present HCS structures and abundant radiolarians, indicating high-energy conditions in the seafloor, the input of pelagic sediment from neighbouring areas, and increasing oxygenation in the sea bottom waters.

Data availability. The data are available in the Supplement.

Supplement. The supplement related to this article is available online at: https://doi.org/10.5194/jm-39-233-2020-supplement.

Competing interests. The author declares that there is no conflict of interest.

Acknowledgements. This work is a contribution of the IGCP655 (UNESCO-IUGS). Constructive comments by Marisa Canales (Univ. Complutense) and an anonymous reviewer are highly appreciated.

Financial support. This research was supported by funding from the Spanish Ministry of Economy and Competitiveness, FEDER funds (project PID2019-105537RB-100), and the RNM-200 research group.

Review statement. This paper was edited by Thomas M. Cronin and reviewed by Marisa Canales and one anonymous referee. 


\section{References}

Aberhan, M. and Fursich, F. T.: Mass origination versus mass extinction: The biological contribution to the Pliensbachian - Toarcian extinction event, J. Geol. Soc. Lond., 157, 55-60, 2000.

Aguado, R., Reolid, M., and Molina, E.: Response of calcareous nannoplankton to the Late Cretaceous Oceanic Anoxic Event 2 at Oued Bahloul (central Tunisia), Palaeogeogr., Palaeocl., 459, 289-305, 2016.

Alegret, L., Reolid, M., and Vega Pérez, M.: Environmental instability during the latest Paleocene at Zumaia (Basque-Cantabric Basin): the bellwether of the Paleocene-Eocene Thermal Maximum, Palaeogeogr. Palaeocl., 497, 186-200, 2018.

Algeo, T. J., Morford, J., and Cruse, A.: New applications of trace metals as proxies in marine paleoenvironments, Chem. Geol., 306-307, 160-164, 2012.

Anderson, T. F. and Arthur, M. A.: Stable isotopes of oxygen and carbon and their application to sedimentologic and paleoenvironmental problems, in: Stable Isotopes in Sedimentary Geology, edited by: Arthur, M. A., Anderson, T. F., Kaplan, L. R., Veizer, J., and Land, L., SEPM, Georgia 1-151, 1983.

Arias, C.: The early Toarcian (early Jurassic) ostracod extinction events in the Iberian Range: The effect of temperature changes and prolonged exposure to low dissolved oxygen concentrations, Palaeogeogr. Palaeocl., 387, 40-55, 2013.

Arias, C. and Whatley, R.: Distribution patterns of Early Jurassic Ostracoda and possible communication routes across the European Epicontinental Sea: evidence changes in ocean circulation patterns and its consequence to climate change, N. Jb. Geol. Palaont. Abh., 232, 1-55, 2004.

Arias, C. and Whatley, R.: Multivariate hierarchical analyses of Early Jurassic Ostracoda assemblages, Lethaia, 42, 495-510, 2009.

Ayress, M. A., De Deckker, P., and Coles, G. P.: A taxonomic and distributional survey of marine benthonic Ostracoda of Kerguelen and Heard Islands, South Indian Ocean, J. Micropal., 23, 1538, 2004.

Baghli, H., Mattioli, E., Spangenberg, J. E., Bensalah, M., ArnaudGodet, F., Pittet, B., and Suan, G.: Early Jurassic climatic trends in the south-Tethyan margin, Gond. Res., 77, 67-81, 2020.

Baroni, I. R., Pohl, A., van Helmond, N. A. G., Papadomanolaki, N. M., Coe, A. L., Cohen, A. S., van de Schootbrugge, B., Donnadieu, Y., and Slomp, C. P.: Ocean circulation in the Toarcian (Early Jurassic): A key control on deoxygenation and carbon burial on the European Shelf, Paleoceanogr. Paleocl., 33, 9941012, 2018.

Bartolini, A., Nocchi, M., Baldanza, A., and Parisi, G.: Benthic life during the Early Toarcian Anoxic Event in the South western Tethyan Umbria-Marche Basin, Central Italy, Studies in Benthic Foraminifera Benthos'90, Tokai University Press, 323-338, 1992.

Bejjaji, Z., Chakiri, S., Reolid, M., and Boutakiout, M.: Foraminiferal biostratigraphy of the Toarcian deposits (Lower Jurassic) from the Middle Atlas (Morocco). Comparison with western Tethyan areas, J. Afr. Earth Sci., 57, 154-162, 2010.

Bellanca, A., Masetti, D., Neri, R., and Venezia, F.: Geochemical and sedimentological evidence of productivity cycles recorded in Toarcian black shales from the Belluno basin, southern Alps, northern Italy, J. Sediment Res., 69, 466-476, 1999.
Benson, R., Del Grosso, R., and Steineck, P.: Ostracode distribution and biofacies, Newfoundland continental slope and rise, $\mathrm{Mi}-$ cropaleontology, 29, 430-453, 1983.

Berner, R. A. and Raiswell, R.: Burial of organic carbon and pyrite sulfur in sediments over Phanerozoic time: a new theory, Geochim. Cosmochim. Ac., 47, 855-862, 1983.

Bodin, S., Mattioli, E., Frölich, S., Marshall, J. D., Boutib, L., Lahsini, S., and Redfern, J.: Toarcian carbon isotope shifts and nutrient changes from the Northern margin of Gondwana (High Atlas, Morocco, Jurassic): palaeoenvironmental implications, Palaeogeogr. Palaeocl., 297, 377-390, 2010.

Bonnet, L., Andreu, B., Rey, J., Cubaynes, R., Ruget, C., N'ZabaMakaya, O., and Brunel, F.: Fluctuations of environmental factors as seen by means of statistical analyses in micropaleontological assemblages from a Liassic Series, Micropaleontology, 45, 399-417, 1999.

Boomer, I. and Whatley, R.: Ostracoda and dysaerobia in the Lower Jurassic of Wales: the reconstruction of past oxygen levels, Palaeogeogr. Palaeocl., 99, 373-379, 1992.

Boomer, I., Lord, A. R., Page, K. N., Bown, P. R., Lowry, F. M. D., and Riding, J. B.: The biostraigraphy of the Upper PliensbachianToarcian (Lower Jurassic) sequence at Ilminster, Somerset, J. Micropalaeontol., 28, 67-85, 2009.

Boomer, L., Lord, A., and Crasquin, S.: The extinction of the Metacopina (Ostracoda). Senckenberg, Lethaea, 88, 47-53, 2008.

Boudchiche, L., Nicollin, J. P., and Ruget, C.: Evolution des assemblages de foraminifères pendant le Toarcien dans le massif des Beni Snassen (Maroc nord-oriental), Géol. Méditerranéenne, 14, 161-166, 1987.

Bucefalo-Palliani, R., Mattioli, E., and Riding, J. B.: The response of marine phytoplankton and sedimentary organic matter to the Early Toarcian (Lower Jurassic) oceanic anoxic event in northern England, Mar. Micropaleontol., 46, 223-245, 2002.

Cabral, M. C., Loureiro, I. M., Duarte, L. V., and Azêredo, A. C.: Registo da extinção dos Metacopina (Ostracoda, Crustacea) no Toarciano de Rabaçal, região de Coimbra, Comun. Geol., 100, 63-68, 2013.

Calvert, S. E.: Geochemistry and origin of the Holocene sapropel in the Black Sea, in: Facets of Modern Biogeochemistry, edited by: Ittekkot, V., Kemp, S., Michaelis, W., and Spitzy, A., Springer, Berlin, 326-352, 1990.

Calvert, S. E. and Pedersen, T. F.: Geochemistry of recent oxic and anoxic marine sediments: Implications for the geological record, Mar. Geol., 113, 67-88, 1993.

Caruthers, A. H., Smith, P. L., and Grocke, D. R.: The Pliensbachian-Toarcian (Early Jurassic) extinction: A North American perspective, GSA Spec. Paper, 505, 20 pp., https://doi.org/10.1130/2014.2505(11), 2014.

Casellato, C. E. and Erba, E.: Calcareous nannofossil biostratigraphy and paleoceanography of the Toarcian Oceanic Anoxic Event at Colle di Sogno (Southern Alps, Northern Italy), Riv. Ital. Paleontol. S., 121, 297-327, 2015.

Caswell, B. A. and Coe, A. L.: A high-resolution shallow marine record of the Toarcian (Early Jurassic) Oceanic Anoxic Event from the East Midlands Shelf, UK, Palaeogeogr. Palaeocl., 365366, 124-135, 2012.

Cecca, F. and Macchioni, F.: The two Early Toarcian (Early Jurassic) extinction events in ammonoids, Lethaia, 37, 35-56, 2004. 
Cheel, R. J. and Leckie, D. A.: Hummocky cross-stratification, in: Sedimentology Review/1, edited by: Wright, P., Blackwell Scientific Publication, London, 103-122, 1993.

Clémence, M. E., Gardin, S., Bartolini, A., Paris, G., Beaumont, V., and Guex, J.: Benthoplanktonic evidence from the Austrian Alps for a decline in sea-surface carbonate production at the end of the Triassic, Swiss J. Geosci., 103, 293-315, 2010.

Copestake, P. and Johnson, B.: Lower Jurassic foraminifera from the Llanbedr (Mochras Farm) Borehole, North Wales, UK, in: Monograph of the Palaeontographical Society, 167 pp., Palaeontographical Society, London, 2014.

Corbari, L.: Physiologie respiratoire, comportementale et morphofonctionnelle des ostracodes Podocopes et Myodocopes et d'un amphipode caprellidé profond. Stratégies adaptatives et implications évolutives, PhD Thesis, University Bordeaux, 300 pp., 2004.

Corbari, L., Carbonel, P., and Massabuau, J.-C.: How a low tissue $\mathrm{O}_{2}$ strategy could be conserved in early crustaceans: the example of the podocopid ostracods, J. Exp. Biol., 207, 4415-4425, 2004.

Corliss, B. H.: Microhabitat of benthic foraminifera with deep sea sediments, Nature, 314, 435-624, 1985.

Corliss, B. H.: Morphology and microhabitat preferences of benthic foraminifera from the northwest Atlantic Ocean, Mar. Micropaleontol., 17, 195-236, 1991.

Cronin, T. M., Holtz Jr., T. R., and Whatley, R. C.: Quaternary paleoceanography of the deep Arctic Ocean based on quantitative analysis of Ostracoda, Mar. Geol., 119, 305-332, 1994.

Cronin, T., Holtz Jr., T. R., Stein, M., Spielhagen, R., Futterer, D., and Wollenburg, J.: Late Quaternary paleoceanography of the Eurasian Basin, Arctic Ocean, Paleoceanography, 10, 259-281, 1995.

Cronin, T., Boomer, I., Dwyer, G. S., and Rodríguez-Lázaro, J.: Ostracoda and paleoceanography, in: The Ostracoda: Applications in Quaternary Research, edited by: Holmes, J. A. and Chivas, A. R., American Geophysical Union, Washington, DC, 99-119, 2002.

Danise, S., Twichett, R. J., Little, C. T. S., and Clemence, M. E.: The impact of global warming and anoxia on marine benthic community dynamics: an example from the Toarcian (Early Jurassic), PLoS ONE, 8, e56255, https://doi.org/10.1371/journal.pone.0056255, 2013.

Danise, S., Clemence, M. E., Price, G. D., Murphy, D. P., Gomez, J. J., and Twitchett, R. J.: Stratigraphic and environmental control on marine benthic community change through the early Toarcian extinction event (Iberian Range, Spain), Palaeogeogr. Palaeocl., 524, 183-200, 2019.

Depêche, F.: Les ostracodes d'une plate-forme continentale au Jurassique. Recherches sur le Bathonien du Bassin parisien, PhD Thesis, Univ. Pierre Marie Curie, Paris, 325 pp., 1984.

Dera, G. and Donnadieu, Y.: Modeling evidences for global warming, Arctic seawater freshening, and sluggish oceanic circulation during the Early Toarcian anoxic event, Paleoceanography, 27, PA2211, https://doi.org/10.1029/2012PA002283, 2012.

Dera, G., Puceat, E., Pellenard, P., Neige, P., Delsate, D., Joachimski, M. M., Reisberg, L., and Martínez, M.: Water mass exchange and variations in seawater temperature in the NW Tethys during the Early Jurassic: evidence from neodymium and oxygen isotopes of fish teeth and belemnites, Earth Planet. Sc. Lett., 286, 198-207, 2009.
Dingle, R. V. and Lord, A.: Benthic ostracods and deep watermasses in the Atlantic Ocean, Palaeogeogr. Palaeocl., 80, 213235, 1990.

Duarte, L. V.: Facies analysis and sequential evolution of the Toarcian-Lower Aalenian series in the Lusitanian Basin (Portugal), Com. Inst. Geol. Min., 83, 65-94, 1997.

Duarte, L. V.: Clay minerals and geochemical evolution in the Toarcian-Lower Aalenian of the Lusitanian Basin, Cuad. Geol. Ibérica, 24, 69-98, 1998.

Duarte, L. V. and Soares, A. F.: Eventos de natureza tempestítica e turbiditíca no Toarciano inferior da Bacia Lusitaniana (Sector Norte), Cad. Geogr. Univ. Coimbra, 12, 89-95, 1993.

Erba, E.: Calcareous nannofossils and Mesozoic oceanic anoxic events, Mar. Micropaleontol., 52, 85-106, 2004.

Ernst, S. and Van der Zwaan, G. B.: Effects of experimentally induced raised levels of organic flux and oxygen depletion on a continental slope benthic foraminiferal community, Deep-Sea Res. Pt. I, 51, 1709-1739, 2004.

Fantasia, A., Follmi, K. B., Adatte, T., Spangenberg, J. E., and Mattioli, E.: Expression of the Toarcian Oceanic Anoxic Event: New insights from a Swiss transect, Sediment, 66, 262-284, 2019.

Fisher, R. A., Corbet, A. S., and Williams, C. B.: The relations between the number of species and the number of individuals in a random sample of an animal population, J. Anim. Ecol., 12, 42-58, 1943.

Fohrer, B. and Samankassou, E.: Paleoecological control of ostracod distribution in a Pennsylvanian Auernig cyclothem of the Carnic Alps, Austria, Palaeogeogr. Palaeocl., 225, 317-330, 2005.

Fontanier, C., Jorissen, F. J., Licari, L., Alexandre, A., Anschutz, P., and Carbonel, P.: Live benthic foraminiferal faunas from the Bay of Biscay: faunal density, composition, and microhabitats, Deep-Sea Res. Pt. I, 49, 751-785, 2002.

Friedrich, O., Erbacher, J., Wilson, P. A., Moriya, K., and Mutterlose, J.: Paleoenvironmental changes across the Mid Cenomanian Event in the tropical Atlantic Ocean (Demerara Rise ODP Leg 207) inferred from benthic foraminiferal assemblages, Mar. Micropaleontol., 71, 28-40, 2009.

Fu, X. G., Wang, M., Zeng, S. Q., Feng, X. L., Wang, D., and Song, C. Y.: Continental weathering and palaeoclimatic changes through the onset of the Early Toarcian oceanic anoxic event in the Qiangtang Basin, Eastern Tethys, Palaeogeogr. Palaeocl., 487, 241-250, 2017.

Gallego-Torres, D., Martínez-Ruiz, F., Paytan, A., Jiménez-Espejo, F. J., and Ortega-Huertas, M.: Pliocene-Holocene evolution of depositional conditions in the Eastern Mediterranean: Role of anoxia vs. productivity at time of sapropel deposition, Palaeogeogr. Palaeocl., 246, 424-439, 2007.

García-Hernández, M., López-Garrido, A. C., Martín-Algarra, A., Molina, J. M., Ruiz-Ortiz, P. A., and Vera, J. A.: Las discontinuidades mayores del Jurásico de las Zonas Externas de las Cordilleras Béticas: Análisis e interpretación de los ciclos sedimentarios, Cuad. Geol. Ibérica, 13, 35-52, 1989.

García Joral, F., Gómez, J. J., and Goy, A.: Mass extinction and recovery of the Early Toarcian (Early Jurassic) brachiopods linked to climate change in northern and central Spain, Palaeogeogr. Palaeocl., 302, 367-380, 2011.

Gatto, R., Monari, S., Neige, P., Pinard, J. D., and Weis, R.: Gastropods from upper Pliensbachian-Toarcian (Lower Jurassic) 
sediments of Causses basin, southern France and their recovery after the early Toarcian anoxic event, Geol. Mag., 152, 871-901, 2015.

Gebhardt, H., Kuhnt, W., and Holbourn, A.: Foraminiferal response to sea level change, organic flux and oxygen deficiency in the Cenomanian of the Tarfaya Basin, southern Morocco, Mar. Micropaleontol., 53, 133-157, 2004.

Gill, B. C., Lyons, T. W., and Jenkyns, H. C.: A global perturbation to the sulfur cycle during the Toarcian Oceanic Anoxic Event, Earth Planet. Sc. Lett., 312, 484-496, 2011.

Gómez, J. J. and Arias, C.: Rapid warming and ostracods mass extinction at the Lower Toarcian (Jurassic) of central Spain, Mar. Micropaleontol., 74, 119-135, 2010.

Gómez, J. J. and Goy, A.: Warming-driven mass extinction in the Early Toarcian (Early Jurassic) of northern and central Spain. Correlation with other time-equivalent European sections, Palaeogeogr. Palaeocl., 306, 176-195, 2011.

Graciansky, P. C., Jacquin, T., and Hesselbo, S. P.: The Ligurian cycle: an overview of Lower Jurassic 2nd-order transgressive/regressive facies cycles in western Europe, SEPM Spec. Pub., 60, 467-479, 1998.

Hallam, A.: Radiations and extinctions in relation to environmental change in the marine Lower Jurassic of northwest Europe, Paleobiology, 13, 152-168, 1987.

Haq, B. U.: Jurassic sea-level variations: a reappraisal, GSA Today, 28, 4-10, 2018.

Harazim, D., van de Schootbrugge, B., Sorichter, K., Fiebig, J., Weug, A., Suan, G., and Oschmann, W.: Spatial variability of watermass conditions within the European Epicontinental Seaway during the Early Jurassic (Pliensbachian-Toarcian), Sediment, 60, 359-390, 2013.

Helz, G. R., Miller, C. V., Charnock, J. M., Mosselmans, J. L. W., Pattrick, R. A. D., Garner, C. D., and Vaughan, D. J.: Mechanisms of molybdenum removal from the sea and its concentration in black shales: EXAFS evidences, Geochim. Cosmochim. Ac., 60, 3631-3642, 1996.

Hermoso, M., Le Callonnec, L., Minoletti, F., Renard, M., and Hesselbo, S. P.: Expression of the Early Toarcian negative carbonisotope excursion in separated carbonate microfractions (Jurassic, Paris Basin), Earth Planet. Sc. Lett., 277, 194-203, 2009.

Herrero, C.: Lower Toarcian foraminifera from the Northern sector of the Iberian Range (Spain), Geobios, 27, 287-295, 1994.

Herrero, C.: Pliensbachian Foraminifera at Camino section (Basque-Cantabrian Basin, Spain), Cuad. Geol. Ibérica, 24, 121139, 1998.

Hesselbo, S. P., Jenkyns, H. C., Duarte, L. V., and Oliveira, L. C. V.: Carbon-isotope record of the Early Jurassic (Toarcian) Oceanic Anoxic Event from fossil wood and marine carbonate (Lusitanian Basin, Portugal), Earth Planet. Sc. Lett., 253, 455-470, 2007.

Hylton, M. D.: Microfaunal Investigation of the Early Toarcian (Lower Jurassic) Extinction Event in NW Europe, PhD Thesis, University of Plymouth, 287 pp., 2000.

Hylton, M. D. and Hart, M. B.: Benthic foraminiferal response to Pliensbachian-Toarcian (Lower Jurassic) sea-level change and oceanic anoxia in NW Europe, Geores. Forum, 6, 455-462, 2000.

Izumi, K., Miyaji, T., and Tanabe, K.: Early Toarcian (Early Jurassic) oceanic anoxic event recorded in the shelf deposits in the northwestern Panthalassa: evidence from the Nishinakayama for- mation in the Toyora area, west Japan, Palaeogeogr. Palaeocl., 315-316, 100-108, 2012.

Izumi, K., Endo, K., Kemp, D. B., and Inui, M.: Oceanic redox conditions through the late Pliensbachian to early Toarcian on the northwestern Panthalassa margin: Insights from pyrite and geochemical data, Palaeogeogr. Palaeocl., 493, 1-10, 2018.

Jenkyns, H. C.: The Early Toarcian and Cenomanian-Turonian anoxic events in Europe: comparisons and contrasts, Geol. Runds., 74, 505-518, 1985.

Jenkyns, H. C.: The early Toarcian (Jurassic) anoxic event - stratigraphic, sedimentary, and geochemical evidence, Am. J. Geosci., 288, 101-151, 1988.

Jenkyns, H. C.: Evidence for a rapid climate change in the Mesozoic-Paleogene greenhouse world, Philos. T. R. Soc., 361, 1885-1916, 2003.

Jenkyns, H. C. and Clayton, C. J.: Black shales and carbon isotopes in pelagic sediments from the Tethyan Lower Jurassic, Sediment, 33, 87-106, 1986.

Jenkyns, H. C., Jones, C. E., Grocke, D. R., Hesselbo, S. P., and Parkinson, D. N.: Chemostratigraphy of the Jurassic System: applications, limitations and implications for palaeoceanography, J. Geol. Soc. Lond., 159, 351-378, 2002.

Jiménez, A. P.: Estudio paleontológico de los ammonites del Toarciense inferior y medio de las Cordilleras Béticas (Dactylioceratidae e Hildoceratidae), PhD Thesis, Univ. Granada, 252 pp., 1986.

Jones, R. W. and Charnock, M. A.: "Morphogroups" of agglutinating foraminifera. Their life position and feeding habits and potential applicability in (paleo)ecological studies, Rev. Paléobiol., 4, 311-320, 1985.

Jorissen, F. J., De Stigter, H. C., and Widmark, J. G. V.: A conceptual model explaining benthic foraminiferal microhabitats, Mar. Micropaleontol., 26, 3-15, 1995.

Józsa, S., Suan, G., and Schlogl, J.: Benthic foraminiferal bioevents in lower to upper Toarcian strata of Southern Beaujolais (SE France), Geobios, 51, 137-150, 2018.

Korte, C. and Hesselbo, S. P.: Shallow marine carbon and oxygen isotope and elemental records indicate icehouse-greenhouse cycles during the early Jurassic, Paleoceanography, 26, PA4219, https://doi.org/10.1029/2011PA002160, 2011.

Krencker, F. N., Bodin, S., Suan, G., Heimhofer, U., Kabiri, L., and Immenhauser, A.: Toarcian extreme warmth led to tropical cyclone intensification, Earth Planet. Sc. Lett., 425, 120-130, 2015.

Kuhnt, W., Moullade, M., and Kaminski, M. A.: Ecological structuring and evolution of deep sea agglutinated foraminifera - a review, Rev. Micropal., 39, 271-281, 1996.

Lethiers, F. and Whatley, R.: The use of ostracoda to reconstruct the oxygen levels of Late Palaeozoic oceans, Mar. Micropaleontol., 24, 57-69, 1994.

Lethiers, F. and Whatley, R.: Oxygenation des eaux et ostracodes filtreurs: Application au Devonien-Dinantien, Geobios, 28, 199207, 1995.

Lezin, C., Andreu, B., Pellenard, P., Bouchez, J. L., Emmanuel, L., Fauré, P., and Lanchem, P.: Geochemical disturbance and paleoenvironmental changes during the Early Toarcian in NW Europe, Chem. Geol., 341, 1-15, 2013.

Little, C. T. S. and Benton, M. J.: Early Jurassic mass extinction: a global long-term event, Geology, 23, 495-498, 1995. 
Loeblich, A. R. and Tappan, H.: Foraminiferal genera and their classifications, Van Noslrand Reinhold (Ed.), New York, 970 pp., 1988.

Mailliot, S., Mattioli, E., Guex, J., and Pittet, B.: The Early Toarcian anoxia, a synchronous event in the Western Tethys? An approach by quantitative biochronology (Unitary Associations), applied on calcareous nannofossils, Palaeogeogr. Palaeocl., 240, 562-586, 2006.

Mailliot, S., Mattioli, E., Bartolini, A., Baudin, F., Pittet, B., and Guex, J.: Late Pliensbachian - Early Toarcian (Early Jurassic) environmental changes in an epicontinental basin of NW Europe (Causses area, central France): a micropaleontological and geochemical approach, Palaeogeogr. Palaeocl., 273, 346-364, 2009.

Marok, A. and Reolid, M.: Lower Jurassic sediments from the Rhar Roubane Mountains (Western Algeria): Stratigraphic precisions and synsedimentary block-faulting, J. Afr. Earth Sci., 76, 50-65, 2012.

Mattioli, E., Pittet, B., Bucefalo-Palliani, R., Röhl, H. J., SchmidRöhl, A., and Morettini, E.: Phytoplankton evidence for the timing and correlation of palaeoceanographical changes during the early Toarcian oceanic anoxic event (Early Jurassic), J. Geol. Soc. Lond., 161, 685-693, 2004.

Mattioli, E., Pittet, B., Suan, G., and Mailliot, S.: Calcareous nannoplankton across the Early Toarcian Anoxic Event: implications for paleoceanography within the western Tethys, Paleoceanography, 23, PA3208, https://doi.org/10.1029/2007PA001435, 2008.

McArthur, J. M.: Early Toarcian black shales: A response to an oceanic anoxic event or anoxia in marginal basins?, Chem. Geol., 522, 71-83, 2019.

McArthur, J. M., Algeo, T. J., van de Schootbrugge, B., Li, Q., and Howarth, R. J.: Basinal restriction, black shales, Re-Os dating, and the Early Toarcian (Jurassic) oceanic anoxic event, Paleoceanography, 23, PA4217, https://doi.org/10.1029/2008PA001607, 2008.

Meyers, S. R., Sageman, B. B., and Lyons, T. W.: Organic carbon burial rate and the molybdenum proxy: theoretical framework and application to CenomanianTuronian oceanic event 2, Paleoceanography, 20, PA2002, https://doi.org/10.1029/2004PA001068, 2005.

Morten, S. D. and Twitchett, R. J.: Fluctuations in the body size of marine invertebrates through the Pliensbachian-Toarcian extinction event, Palaeogeogr. Palaeocl., 284, 29-38, 2009.

Montero-Serrano, J. C., Follmi, K. B., Adatte, T., Spangenberg, J. E., Tribovillard, N., Fantasia, A., and Suan, G.: Continental weathering and redox conditions during the early Toarcian Oceanic Anoxic Event in the northwestern Tethys: Insight from the Posidonia Shale section in the Swiss Jura Mountains, Palaeogeogr. Palaeocl., 429, 83-99, 2015.

Müller, T., Price, G. D., Bajnai, D., Nyerges, A., Kesjar, D., Raucsik, B., Varga, A., Judik, K., Fekete, J., May, Z., and Palfy, J.: New multiproxy record of the Jenkyns Event (also known as the Toarcian Oceanic Anoxic Event) from the Mecsek Mountains (Hungary): Differences, duration and drivers, Sediment, 64, 6686, 2017.

Müller, T., Jurikova, H., Gutjahr, M., Tomašovych, A., Schlögl, J., Liebetrau, V., Duarte, L.V., Milovsky, R., Suan, G., Mattioli, E., Pittet, B., and Eisenhauer, A.: Ocean acidification during the early Toarcian extinction event: evidence from boron isotopes in brachiopods, Geology, 48, 1184-1188, https://doi.org/10.1130/G47781.1, 2020.

Nagy, J.: Environmental significance of foraminiferal morphogroups in Jurassic North Sea deltas, Palaeogeogr. Palaeocl., 95, 111-134, 1992.

Nicollin, J. P., Faure, P., and Ruget, C.: Le Toarcien inférieur, période charnière dans lévolution des nodosariides (foraminifères): lexemple des Pyrénées Méridionales du Haut-Aragon, Geobios MS, 18, 347-356, 1995.

Nieto, L. M., Molina, J. M., and Ruiz-Ortiz, P. A.: La Formación Zegrí: registro de los primeros estadios de una etapa sin-rift en el Jurásico de las Zonas Externas Béticas, Geotemas, 6, 157-160, 2004.

Nikitenko, B. L., Reolid, M., and Glinskikh, L.: Ecostratigraphy of benthic foraminifera for interpreting Arctic record of Early Toarcian biotic crisis (Northern Siberia, Russia), Palaeogeogr. Palaeocl., 376, 200-212, 2013.

Nocchi, M. and Bartolini A.: Investigation on Late DomerianEarly Toarcian Lagenina and Glomospirella assemblages in the Umbria-Marche Basin (Central Italy), Geobios MS, 17, 689699, 1994.

N'Zaba-Makaya, O., Andreu, B., Brunel, F., Mouterde, R., Rey, J., and Rocha, R. B.: Biostratigraphie et paléoécologie des peuplements d'ostracodes dans le Domérien du Bassin Lusitanien, Portugal, Ciências da Terra, 15, 21-44, 2003.

Olóriz, F., Reolid, M., and Rodríguez-Tovar, F. J.: Palaeogeographic and stratigraphic distribution of mid-late Oxfordian foraminiferal assemblages in the Prebetic Zone (Betic Cordilllera, Southern Spain), Geobios, 36, 733-747, 2003

Olóriz, F., Reolid, M., and Rodríguez-Tovar, F. J.: Palaeogeography and relative sealevel history forcing eco-sedimentary contexts in Late Jurassic epicontinental shelves (Prebetic Zone, Betic Cordillera): an ecostratigraphic approach, Earth-Sci. Rev., 111, 154-178, 2012.

Palomo, I.: Mineralogía y geoquímica de sedimentos pelágicos del Jurásico Inferior de las Cordilleras Béticas (SE de España), PhD Thesis, Univ. Granada, 345 pp., 1987.

Parisi, G., Ortega-Huertas, M., Nocchi, M., Palomo, I., Monaco, P., and Ruiz, F.: Stratigraphy and geochemical anomalies of the Early Toarcian oxygen-poor interval in the Umbria-Marche Apennines (Italy), Geobios, 29, 469-484, 1996.

Pawloski, J., Holzmann, M., and Tyszka, J.: New supraordinal classification of Foraminifera: Molecules meet morphology, Mar. Micropaleontol., 100, 1-10, 2013.

Peypouquet, J.-P., Ducasse, O., and Rousselle, L.: Morphogenesis and environment. Theoretical and practical aspect from Hammatocythere: Paleogene Ostracods of the Aquitaine Basin, in: Concepts and Methods in Paleontology, edited by: Martinell, J., University of Barcelona, Barcelona, 173-187, 1981.

Piazza, V., Ullman, C. V., and Aberhan, M.: Temperature-related body size change of marine benthic macroinvertebrates across the Early Toarcian Anoxic Event, Sci. Rep.-UK, 10, 4675, https://doi.org/10.1038/s41598-020-61393-5, 2020.

Pittet, B., Suan, G., Lenoir, F., Duarte, L. V., and Mattioli, E.: Carbon isotope evidence for sedimentary discontinuities in the lower Toarcian of the Lusitanian Basin (Portugal): sea-level change at the onset of the Oceanic Anoxic Event, Sediment. Geol., 303, 1-14, 2014. 
Pörtner, R. O.: Oxygen- and capacity-limitation of thermal tolerance: a matrix for integrating climate-related stressor effects in marine ecosystems, J. Exp. Biol., 213, 881-893, 2010.

Powell, W. G., Johnston, P. A., and Collom, C. J.: Geochemical evidence for oxygenated bottom waters during deposition of fossiliferous strata of the Burgess Shale Formation, Palaeogeogr. Palaeocl., 201, 249-268, 2003.

Reolid, M.: Taphonomic features of Lenticulina as a tool for palaeoenvironmental interpretation of mid-shelf deposits of Upper Jurassic (Prebetic Zone, Southern Spain), Palaios, 23, 482494, 2008.

Reolid, M.: Stable isotopes on foraminifera and ostracods for interpreting incidence of the Toarcian Oceanic Anoxic Event in Westernmost Tethys: role of water stagnation and productivity, Palaeogeogr. Palaeocl., 395, 77-91, 2014a.

Reolid, M.: Pyritized radiolarians and siliceous sponges from oxygen restricted deposits (Lower Toarcian, Jurassic), Facies, 60, 789-799, 2014b.

Reolid, M., Nagy, J., Rodríguez-Tovar, F. J., and Olóriz, F.: Foraminiferal assemblages as palaeoenvironmental bioindicators in Late Jurassic epicontinental platforms: Relation with trophic conditions, Acta Palaeontol. Pol., 53, 706-722, 2008a.

Reolid, M., Rodríguez-Tovar, F. J., Nagy, J., and Olóriz, F.: Benthic foraminiferal morphogroups of mid to outer shelf environments of the Late Jurassic (Prebetic Zone, Southern Spain): characterization of biofacies and environmental significance, Palaeogeogr. Palaeocl., 261, 280-299, 2008b.

Reolid, M., Rodríguez-Tovar, F. J., Marok, A., and Sebane, A.: The Toarcian Oceanic Anoxic Event in the Western Saharan Atlas, Algeria (North African Paleomargin): role of anoxia and productivity, GSA Bull., 124, 1646-1664, 2012a.

Reolid, M., Sebane, A., Rodríguez-Tovar, F. J., and Marok, A.: Foraminiferal morphogroups as a tool to approach Toarcian Anoxic Event in the Western Saharan Atlas (Algeria), Palaeogeogr. Palaeocl., 323, 87-99, 2012b.

Reolid, M., Chakiri, S., and Bejjaji, Z.: Adaptative strategies of the Toarcian benthic foraminiferal assemblages from the Middle Atlas (Morocco): palaeoecological implications, J. Afr. Earth Sci., 84, 1-12, 2013.

Reolid, M., Mattioli, E., Nieto, L. M., and Rodríguez-Tovar, F. J.: The Early Toarcian Ocanic Anoxic Event in the External Subbetic (Southiberian Palaeomargin, Westernmost Tethys): geochemistry, nannofossils and ichnology, Palaeogeogr. Palaeocl., 411, 79-94, 2014a.

Reolid, M., Marok, A., and Sebane, A.: Foraminiferal assemblages and geochemistry for interpreting the incidence of Early Toarcian environmental changes in North Gondwana palaeomargin (Traras Mountains, Algeria), J. Afr. Earth Sci., 95, 105-122, 2014b.

Reolid, M., Rivas, P., and Rodríguez-Tovar, F. J.: Toarcian ammonitico rosso facies from the South Iberian Paleomargin (Betic Cordillera, southern Spain): paleoenvironmental reconstruction, Facies, 61, 22, https://doi.org/10.1007/s10347-0150447-3, 2015.

Reolid, M., Sánchez-Quiñónez, C. A., Alegret, L., and Molina, E.: The biotic crisis across the Oceanic Anoxic Event 2: Palaeoenvironmental inferences based on foraminifera and geochemical proxies from the South Iberian Palaeomargin, Cret. Res., 60, 127, 2016.
Reolid, M., Molina, J. M., Nieto, L. M., and Rodríguez-Tovar, F. J.: The Toarcian Oceanic Anoxic Event in the South Iberian Palaeomargin, Springer Briefs in Earth Sciences, 122 pp., 2018.

Reolid, M., Duarte, L. V., and Rita, P.: Changes in foraminiferal assemblages and environmental conditions during the T-OAE (Early Jurassic) in the northern Lusitanian Basin, Portugal, Palaeogeogr. Palaeocl., 520, 30-43, 2019a.

Reolid, M., Copestake, P., and Johnson, B.: Foraminiferal assemblages, extinctions and appearances associated with the Early Toarcian Oceanic Anoxic Event in the Llanbedr (Mochras Farm) Borehole, Cardigan Bay Basin, United Kingdom, Palaeogeogr. Palaeocl., 532, 109277, https://doi.org/10.1016/j.palaeo.2019.109277, 2019b.

Reolid, M., Mattioli, E., Duarte, L. V., and Marok, A.: The Toarcian Oceanic Anoxic Event and the Jenkyns Event (IGCP-655 final report), Episodes 43, 833-844, https://doi.org/10.18814/epiiugs/2019/019018, 2020a.

Reolid, M., Iwańczuk, J., Mattioli, E., and Abad, I.: Integration of gamma ray spectrometry, magnetic susceptibility and calcareous nannofossils for interpreting environmental perturbations: An example from the Jenkyns Event (lower Toarcian) from South Iberian Palaeomargin (Median Subbetic, SE Spain), Palaeogeogr. Palaeocl., 560, https://doi.org/10.1016/j.palaeo.2020.110031, 2020 b.

Rey, J., Bonnet, L., Cubaynes, R., Qajoun, A., and Ruget, C.: Sequence stratigraphy and biological signals: statistical studies of benthic foraminifera from Liassic series, Palaeogeogr. Palaeocl., 111, 149-171, 1994.

Riegraf, W.: Mikrofauna, Biostratigraphie und Fazies im Unteren Toarcium Sudwestdeutschlands und Vergleiche mit benachbarten Gebieten, Tubinger Mikropaläontologische Mitteilungen, 3, 1232, 1985.

Rita, P., Reolid, M., and Duarte, L. V.: Benthic foraminiferal assemblages record major environmental perturbations during the Late Pliensbachian - Early Toarcian interval in the Peniche GSSP, Portugal, Palaeogeogr. Palaeocl., 454, 267-281, 2016.

Rodrigues, B., Silva, R. L., Reolid, M., Mendonca Filho, J. G., and Duarte, L. V.: Sedimentary organic matter and $\delta^{13} \mathrm{C}_{\text {kerogen variation on the southern Iberian palaeo- }}$ margin (Betic Cordillera, SE Spain) during the latest Pliensbachian-Early Toarcian, Palaeogeogr. Palaeocl., 534, 109342, https://doi.org/10.1016/j.palaeo.2019.109342, 2019.

Rodríguez-Tovar, F. J. and Reolid, M.: Environmental conditions during the Toarcian Oceanic Anoxic Event (T-OAE) in the westernmost Tethys: influence of the regional contexto $n$ a global phenomenon, Bull. Geosci., 66, 697-712, 2013.

Rodríguez-Tovar, F. J. and Uchman, A.: Ichnofabric evidence for the lack of bottom anoxia during the Lower Toarcian Oceanic Anoxic Event (T-OAE) in the Fuente de la Vidriera section, Betic Cordillera, Spain, Palaios, 25, 576-587, 2010.

Röhl, H. J., Schmid-Röhl, A., Oschmann, W., Frimmel, A., and Schwark, L.: The Posidonia Shale (Lower Toarcian) of SW Germany: an oxygen-depleted ecosystem controlled by sea-level and palaeoclimate, Palaeogeogr. Palaeocl., 165, 27-52, 2001.

Rosales, I., Quesada, S., and Robles, S.: Paleotemperature variations of Early Jurassic seawater recorded in geochemical trends of belemnites from the Basque-Cantabrian Basin, northern Spain, Palaeogeogr. Palaeocl., 203, 253-275, 2004. 
Ruebsam, W., Müller, T., Kovacs, J., Palfy, J., and Schwark, L.: Environmental response to the early Toarcian carbon cycle and climate perturbation in the northeastern part of the West Tethys shelf, Gond. Res., 59, 144-158, 2018.

Ruebsam, W., Reolid, M., and Schwark, L.: $\delta^{13} \mathrm{C}$ of terrestrial vegetation records Toarcian $\mathrm{CO}_{2}$ and climate gradients, Sci. Rep.-UK, 10, 117, https://doi.org/10.1038/s41598-019-56710-6, 2020a.

Ruebsam, W., Reolid, M., Marok, A., and Schwark, L.: Drivers of benthic extinction during the early Toarcian (Early Jurassic) at the northern Gondwana paleomargin: implications for paleoceanographic conditions, Earth-Sci. Rev., 203, 103117, https://doi.org/10.1016/j.earscirev.2020.103117, 2020 b.

Ruebsam, W., Reolid, M., Sabatino, N., Masetti, D., and Schwark, L.: Molecular paleothermometry of the early Toarcian climate perturbation, Global Planet. Change, 195, 103351, https://doi.org/10.1016/j.gloplacha.2020.103351, 2020c.

Sælen, G., Doyle, P., and Talbot, M. R.: Stable-isotope analyses of belemnite rostra from the Whitby Mudstone Fm, England: surface water conditions during deposition of a marine black shale, Palaios, 11, 97-117, 1996.

Sælen, G., Tyson, R. V., Telnæs, N., and Talbot, M. R.: Contrasting watermass conditions during deposition of the Whitby Mudstone (Lower Jurassic) and Kimmeridge Clay (Upper Jurassic) formations, UK, Palaeoecol. Palaeogeogr., 163, 163-196, 2000.

Sjoerdsma, P. G. and Van der Zwaan, G. J.: Simulating the effect of changing organic flux and oxygen content on the distribution of benthic foraminifers, Mar. Micropaleontol., 19, 1-2, 1992.

Sohn, I. G.: Paleozoic species of Bairdia and related genera: revision of some Paleozoic ostracod genera, U.S. Geological Survey Prof. Pap., 330-B, 107-160, 1960.

Soulimane, C., Reolid, M., Rita, P., Marok, A., and Duarte, L. V.: Uppermost Pliensbachian-lowermost Toarcian ostracod assemblages from the Western Tethys: Comparison between Traras Mountains (Algeria), Subbetic (Spain), and Algarve (Portugal), Ann. Paleontol., 4, 251-269, 2017a.

Soulimane, C., Reolid, M., and Marok, A.: Ostracod assemblages from the uppermost Pliensbachian and Lower Toarcian of the Traras Mountains (Tlemcen Domain, north Algeria), Arab. J. Geosci., 10, 393, https://doi.org/10.1007/s12517-017-3180-0, $2017 b$.

Soulimane, C., Marok, A., and Reolid, M.: Similarity analysis of ostracoda faunas in the Western Tethys during the Late Pliensbachian-Early Toarcian (Early Jurassic), Arab. J. Geosci., 13, 136, https://doi.org/10.1007/s12517-020-5178-2, 2020.

Soussi, M. and Ben Ismail, M. H.: Platform collapse and pelagic seamount facies: Jurassic development of central Tunisia, Sediment. Geol., 133, 93-113, 2000.

Storm, M. S., Hesselbo, S. P., Jenkyns, H. C., Ruhl, M., Ullmann, C. V., Xu, W., Leng, M., Riding, J., and Gorbanenko, O.: Orbital pacing and secular evolution of the Early Jurassic carbon cycle, P. Natl. Acad. Sci. USA, 117, 3974-3982, https://doi.org/10.1073/pnas.1912094117, 2020.

Suan, G., Pittet, B., Bour, I., Mattioli, E., Duarte, L. V., and Mailliot, S.: Duration of the Early Toarcian carbon isotope excursion deduced from spectral analysis: consequence for its possible causes, Earth Planet. Sc. Lett., 267, 666-679, 2008.

Suan, G., Mattioli, E., Pittet, B., Lecuyer, C., Suchéras-Marx, B., Duarte, L. V., Philippe, M., Reggiani, L., and Martineau, F.: Sec- ular environmental precursors to Early Toarcian (Jurassic) extreme climate changes, Earth Planet. Sc. Lett., 290, 448-458, 2010.

Suan, G., Nikitenko, B. L., Rogov, M. A., Baudin, F., Spangenberg, J. E., Knyazev, V. G., Glinskikh, L. A., Goryacheva, A. A., Adatte, T., Riding, J. B., Follmi, K. B., Pittet, B., Mattioli, E., and Lecuyer, C.: Polar record of Early Jurassic massive carbon injection, Earth Planet. Sc. Lett., 312, 102-113, 2011.

Suan, G., Rulleau, L., Mattioli, E., Suchéras-Marx, B., Rousselle, B., Pittet, B., Vincent, P., Martin, J. E., Lena, A., Spangenberg, J. E., and Föllmi, K. B.: Palaeoenvironmental significance of Toarcian black shales and event deposits from southern Beaujolais, France, Geol. Mag., 150, 728-742, 2013.

Suan, G., Schollhorn, I., Schlogl, J., Segit, T., Mattioli, E., Lecuyer, C., and Fourel, F.: Euxinic conditions and high sulfur burial near the European shelf margin (Pieniny Klippen Belt, Slovakia) during the Toarcian oceanic anoxic event, Global Planet. Change, 170, 246-259, 2018.

Teichert, S. and Nutzel, A.: Early Jurassic anoxia triggered the evolution of the oldest holoplanktonic gastropod Coelodiscus minutus by means of heterochrony, Acta Palaeontol. Pol., 60, 269276, 2014.

Them, T. R., Gill, B. C., Selby, D., Grocke, D. R., Friedman, R. M., and Owens, J. D.: Evidence for rapid weathering response to climatic warming during the Toarcian Oceanic Anoxic Event, Sci Rep.-UK, 7, 5003, https://doi.org/10.1038/s41598-017-05307-y, 2017.

Them, T. R., Gill, B. C., Carutherns, A. H., Gerhardt, A. M., Grocke, D. R., Lyons, T. W., Marroquin, S. M., Nielsen, S. G., Alexandre, J. P. T., and Owens, J. D.: Thallium isotopes reveal protracted anoxia during the Toarcian (Early Jurassic) associated with volcanism, carbon burial, and mass extinction, P. Natl. Acad. Sci. USA, 115, 6596-6601, 2018.

Thibault, N., Ruhl, M., Ullmann, C. V., Korte, C., Kemp, D. B., Gröcke, D. R., and Hesselbo, S. P.: The wider context of the Lower Jurassic Toarcian oceanic anoxic event in Yorkshire coastal outcrops, UK, P. Geol. Assoc., 129, 372-391, 2018.

Thomson, J., Mercone, D., de Lange, G. J., and Van Santvoort, P. J. M.: Review of recent advances in the interpretation of eastern Mediterranean sapropel S1 from geochemical evidence, Mar. Geol., 153, 77-89, 1999.

Tremolada, F., van de Schootbrugge, B., and Erba, E.: Early Jurassic schizosphaerellid crisis in Cantabria. Spain: Implications for calcification rates and phytoplankton evolution across the Toarcian oceanic anoxic event, Paleoceanography, 20, 1-11, https://doi.org/10.1029/2004PA001120, 2005.

Tribovillard, N., Algeo, T. J., Lyons, T., and Riboulleau, A.: Trace metals as paleoredox and paleoproductivity proxies: an update, Chem. Geol., 232, 12-32, 2006.

Twitchett, R. J.: The Lilliput effect in the aftermath of the endPermian extinction event, Palaeogeogr. Palaeocl., 252, 132-144, 2007.

Tyszka, J.: Response of Middle Jurassic benthic foraminiferal morphogroups to dysoxic/anoxic conditions in the Pieniny Klippen Basin, Polish Carpathians, Palaeogeogr. Palaeocl., 110, 55-81, 1994.

Urbanek, A.: Biotic crisis in the history of upper Silurian graptoloids: a palaeobiological model, Hist. Biol., 7, 29-50, 1993. 
Van der Zwaan, G. J., Duijnstee, I. A. P., Den Dulk, M., Ernst, S. R., Jannink, N. T., and Kouwenhoven, T. J.: Benthic foraminifers: proxies or problem? A review of paleoecological concepts, Earth-Sci. Rev., 46, 213-236, 1999.

Vera, J. A.: Evolution of the South Iberian Continental Margin, Mémoir Mus. Natl. Hist., 186, 109-143, 2001.

Wasim, S. M., Reolid, M., Talib, A., and Alvi, S. H.: Callovian to Oxfordian benthic foraminifera from Ler Dome, Kutch Basin (Gujarat, India): Systematic, ecostratigraphy and palaeoenvironmental reconstruction, Riv. Ital. Paleontol. S., 126, 315-358, 2020.

Watkinson, M. P.: Triassic to Middle Jurassic sequences from the Lusitanian Basin Portugal, and their equivalents in other North Atlantic margin basins, PhD thesis, Open University Milton Keynes, 441 pp., 1989.

Whatley, R. C.: Ostracoda and palaeogeography, in: Ostracoda in the Earth Sciences, edited by: Deckker, P., Colin, J. P., and Peypouquet, J. P., Elsevier, Amsterdam, 1988.

Whatley, R. C.: The platycopid signal: a means of detecting kenoxic events using Ostracoda, J. Micropalaeontol., 10, 181-183, 1991.

Whatley, R. C.: Ostracoda and oceanic palaeoxygen levels, Mitt. Hamburg. Zool. Mus. Inst., 92, 337-353, 1995.

Whatley, R. C., Arias, C., and Comas Rengifo, M. J.: The use of Ostracoda in detailing kenoxic events: an example from the Spanish Toarcian, Geobios, 17, 733-741, 1994.
Whatley, R., Pyne, R., and Wilkinson, I.: Ostracoda and palaeooxygen levels, with particular reference to the Upper Cretaceous of East Anglia, Palaeogeogr. Paleocl., 194, 355-386, 2003.

Wignall, P. B., Newton, R. J., and Little, C. T. S.: The timing of paleoenvironmental change and cause-and-effect relationships during the Early Jurassic mass extinction in Europe, Am. J. Sci., 305, 1014-1032, 2005.

Xu, W., Ruhl, M., Jenkyns, H. C., Leng, M. J., Huggett, J. M., Minisini, D., Ullmann, C. V., Riding, J. B., Weijers, J. W. H., Storm, M. S., Percival, L. M. E., Tosca, N. J., Idiz, E. F., Tegelaar, E. W., and Hesselbo, H. P.: Evolution of the Toarcian (Early Jurassic) carbon cycle and global climatic controls on local sedimentary processes (Cardigan Bay Basin, UK), Earth Planet. Sc. Lett., 484, 396-411, 2018.

Zhang, J., Fan, T., Zhang, Y., Lash, G. G., Li, Y., and $\mathrm{Wu}$, Y.: Heterogeneous oceanic redox conditions through the Ediacaran-Cambrian boundary limited the metazoan zonation, Sci. Rep.-UK, 7, 8850, https://doi.org/10.1038/s41598-01707904-3, 2017. 